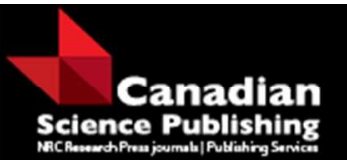

Canadian Journal of Forest Research Revue canadienne de recherche forestière

\title{
Consequences of mountain pine beetle outbreak on forest ecosystem services in western Canada
}

\begin{tabular}{|r|l|}
\hline Journal: & Canadian Journal of Forest Research \\
\hline Manuscript ID & cjfr-2016-0137.R1 \\
\hline Manuscript Type: & Review \\
\hline Date Submitted by the Author: & 02-Jun-2016 \\
\hline Complete List of Authors: & $\begin{array}{l}\text { Dhar, Amalesh; University of British Columbia, Okanagan Institute for } \\
\text { Biodiversity, Resilience, and Ecosystem Services (BRAES) } \\
\text { Parrott, Lael; University of British Columbia, Okanagan, Institute for } \\
\text { Biodiversity, Resilience, and Ecosystem Services } \\
\text { Heckbert, Scott; Alberta Innovates Technology Futures }\end{array}$ \\
\hline Keyword: & $\begin{array}{l}\text { Ecosystem function, lodgepole pine, provisioning services, regulating } \\
\text { services, salvage logging }\end{array}$ \\
\hline &
\end{tabular}

SCHOLARONE $^{\text {Im }}$

Manuscripts 
1

2

3

4

5

6

7

8

9

10

\title{
Consequences of mountain pine beetle outbreak on forest ecosystem services in western Canada
}

\author{
Amalesh Dhar ${ }^{a *}$, Lael Parrott $^{\mathrm{a}}$, Scott Heckbert ${ }^{\mathrm{b}}$
}

a. Okanagan Institute for Biodiversity, Resilience, and Ecosystem Services (BRAES)

University of British Columbia, Okanagan Campus

1177 Research Road

Kelowna, BC, V1V 1V7, Canada

Email: 1ael.parrott@ubc.ca

b. Alberta Innovates Technology Futures

250 Karl Clark Road

Edmonton, Alberta, T6N 1E4, Canada

Email: scott.heckbert@albertainnovates.ca

* Present address and author to whom correspondence should be addressed: Department of Renewable Resources

University of Alberta

847 General Service building

Edmonton, AB, Canada, T6G2H1

Phone: +1-780-492-6538

Email: amalesh@ualberta.ca 


\title{
Consequences of mountain pine beetle outbreak on forest ecosystem services in western Canada
}

\begin{abstract}
After affecting millions of hectares of pine forests in western Canada, the mountain pine beetle (MPB) is spreading out of its native range and into Canada's boreal forest. Impacts of outbreaks can be environmental, economic, and social, and an ecosystem services (ES) viewpoint provides a useful perspective for an integrated approach to assessing these impacts as well as may help to identify how possible management strategies could minimize these impacts. In this regards, a comprehensive overview of the ecosystem functions and socio-economic factors that have been impacted by the current outbreaks in western Canada was carried out to facilitate a more general ES assessment. In addition to timber production, current MPB outbreaks have negative effects on provisioning services (water supply and food production) and aesthetic cultural services, while effects on regulating services (carbon and forest fire) are still in debate. Among the supporting services, nutrient cycling and aquatic habitat showed short and long term negative effects while terrestrial habitat showed a mostly positive response. The overall impact on ES may be more severe if salvage logging is practiced as a post-MPB forest management strategy. The outcomes of this study may help to identify areas of greatest socio-ecological vulnerability to MPB, and identify knowledge gaps and avenues for research to advance the ES framework for MPB outbreak management.
\end{abstract}

Key words: Ecosystem function; lodgepole pine; provisioning services; regulating services; salvage logging 


\section{Introduction}

Outbreaks of mountain pine beetle (MPB) (Dendroctonous ponderosae Hopkins) are natural phenomena that play a critical role in the development of western North American pine forests (Safranyik and Carroll 2006; Negrón and Fettig 2014). Beetles are part of a natural cycle that helps to maintain biologically diverse and functionally healthy forest landscapes (Axelson et al. 2009) by opening gaps in the forest canopy that permit understory regeneration, and by creating habitat for avian and other species that use the standing deadwood. Patterns of MPB outbreaks appear to be changing with the changing climate and degree of human intervention (active forest management) in the forest (Taylor and Carroll 2004; Bentz et al. 2010). Forest management (e.g., harvest regulation, fire suppression) has increased the abundance of susceptible pines (Pinus spp.) in western Canadian forests, and warming climates (warmer summer, milder winter) are expanding the geographic range over which the beetle can complete its life cycle (Logan and Powell 2001; Carroll et al. 2006). As a result, over the past 15 years, the MPB population has expanded exponentially across its native range in lodgepole pine (Pinus contorta var. latifolia Dougl. ex Loud.) stands in British Columbia (BC) and moved east of the Rocky Mountains, spreading through boreal lodgepole and jack (Pinus banksiana Lamb.) pine stands in Alberta (McIntosh and Macdonald 2013; Erbilgin et al. 2014). Generally, MPB burrow into the stems of susceptible pine trees, killing the host tree within a year of establishment. Female beetles lay their eggs along the sides of vertical galleries they excavate in the inner bark of the mature tree. Once the eggs hatch, the beetle larvae feed on the phloem tissue of the tree and disrupt nutrient flow and eventually start damaging the host plant (Safranyik and Carroll 2006). MPB usually overwinter as larvae, completing their development the following spring, pupating in June or July, and finally the adults emerge in mid to late summer (Safranyik and Carroll 2006). Typically, MPB attacks larger-diameter (DBH $>20 \mathrm{~cm}$ ) (Amman et al. 
1977) and older trees (> 60 years) (Shore et al. 2006). However, the current MPB outbreak is more widespread and severe than in the past, and MPB has also been observed colonizing younger trees and stands (even 13 years of age and $7.5 \mathrm{~cm} \mathrm{DBH}$ ) in the absence of mature trees and stands (Maclauchlan 2006; Dhar et al. 2015). According to Shore et al. (2006), lodgepole pine mortality may approach $100 \%$ in mature stands growing in high climatic hazard areas, but landscape mortality levels rates may more typically range from 25 to $50 \%$. The current outbreak has impacted over 20 million hectares (Mha) of pine forests (18.5 Mha in BC and 1.54 Mha in Alberta) in western Canada, with partial to complete (stands with $100 \%$ pine) tree mortality since the current outbreak started in the late 1990s (AESRD 2012a; McIntosh and Macdonald 2013; Walton 2013). The eastward expansion of MPB outbreaks could extend to other native pine species across the boreal forest. However, this expansion is dependent on the availability of suitable climatic conditions (Bentz et al. 2010) and beetle population densities (McIntosh and Macdonald 2013). It has been predicted that boreal pine forests may lose $30 \%$ of their density or $40 \%$ to $60 \%$ of their standing volume if the intensity of attack is similar to what was observed in lodgepole forests BC (Nealis and Peter 2008). Additionally, in the boreal region, lodgepole and jack pine often form even-aged, monospecific stands after fires, increasing the forest's susceptibility to a mass MPB outbreak. Stand and landscape-level mortality and ES impacts due to MPB thus have the potential to be greater compared to other insect outbreaks for spruce or fir that are typically found in mixed boreal forests. In $\mathrm{BC}$ and Alberta, wood from pine forests comprises 25\% (Abbott et al. 2008) and 41\% (based on coniferous harvest together with lodgepole and jack pine) (AESRD 2012a) of the province's timber supplies, respectively. The economic value of BC's wood products (all conifers harvested) was $\$ 9.07$ billion (B)/yr (all monetary values presented in this article are given in Canadian dollars) in 2010, with \$7.6 B/yr ( 30\% of BC’s total export) annual timber export value (BC Ministry of Forests Mines and Lands 2010) and 64,800 direct jobs (7\% of the total BC 
111 workforce). As of 2013, BC forest industries contributed \$2.5 B annually in revenues to the three

112 levels of government (local, provincial, and federal) and $2.5 \%$ of provincial gross domestic product

113 (GDP) (MNP 2015). In Alberta, provincial tax from the forest industry netted \$836 M in stumpage

114 and forestry provides 13,000 jobs (AESRD 2012a; Alberta Government 2012). In addition to

115 extensive timber losses, widespread MPB-caused tree mortality in pine forests may have significant

116 implications for structural components of the ecosystem (e.g. vegetation, water, soil, etc.)

117 (McCullough et al. 1998), and hence ecosystem services (ES). ES are the benefits humans derive

118 from nature (MEA 2005; TEEB 2010), and are generated from natural capital "stocks" from which

119 ES flows like interest or dividends from those stocks (TEEB 2010). The concept of ES has emerged

120 as a formal approach to describe, and categorize the relationship between ecosystems and society and

121 has become a prominent basis for planning and management in many regions worldwide (Daily

122 1997; Mooney and Ehrlich 1997). We propose that ES be considered in forest management decision

making in support of adaptive management of existing areas impacted by MPB (i.e., in the provinces

124 of BC and Alberta) and mitigation efforts in potentially susceptible areas (Saskatchewan and

125 northeastern boreal forests). Doing so would provide a framework for assessing and minimizing the

126 cumulative social, economic, and ecological consequences of outbreaks in western Canada.

127 In western Canada, the MPB-impacted forests are the sources of numerous essential ES (e.g.,

128 timber, fish, other forest products, fresh water, habitat for plants and animals, and recreational

129 activities) that enhance quality of life and wellbeing for local people (Campbell et al. 2009) and that

130 benefit humans at larger scales. The current MPB outbreak has severely altered and affected many of

131 these ES. Despite large numbers of studies about MPB impact on timber, post-beetle stand dynamics,

132 carbon dynamics, hydrology, and wildlife (Abbott et al. 2008; Kurz et al. 2008; Bravi and Chapman

133 2009; Coates et al. 2009; Alfaro et al. 2010, Bunnell et al. 2011; Schnorbus 2011; Hawkins et al

134 2012; Hawkins et al. 2013; Saab et al. 2014; Hansen et al. 2015; Hart et al. 2015; Dhar et al. 2015), 
researchers have rarely addressed the connections between MPB impact and ES. Moreover, an ES based approach would provide a more comprehensive and holistic assessment than separate studies can do, and would account for the myriad interconnections among impacts, ecological functions, and ES. We have, therefore, compiled this review to synthesize information that only relates to the consequences of MPB outbreaks on the overall forest ecosystem and the services it provides. Our focus is pine forests in western Canada, which are experiencing the largest MPB outbreak in recorded history (Alfaro et al. 2010; Hawkins et al. 2012), and may significantly alter the ecosystem functions on a local and regional scale. Therefore, the consequences of current MPB outbreaks become a significant challenge for forest managers, researchers, and practitioners of these areas. In addition, the area affected in western Canada is topographically diverse and includes boreal, montane and dry interior forest types, and thus may serve as an example for other regions. The main objectives of this review paper are threefold: a) to review and synthesize information related to the impact of MPB outbreaks on ES; b) to describe the impact of MPB outbreaks on societal and ecosystem processes that affect ES; and c) to provide a brief outline of the consequences of current management policy on ES in MPB-impacted stands.

\section{Ecosystem services impacted by MPB}

Ecosystems provide a range of services that are of fundamental importance to human wellbeing, health, livelihoods, and survival (Costanza et al., 1997; Costanza et al. 2014; MEA 2005; TEEB 2010), with the concept of ES providing an operational understanding pursued in recent years by the UN Environment Programme under the Economics of Ecosystems and Biodiversity (TEEB) initiative (TEEB 2010). These ES can be categorized into four groups (MEA 2005): i) provisioning services (i.e. timber, food, water, and other products obtained from ecosystems), ii) regulating services (obtained from the regulation of the natural environment by ecosystem processes, i.e., fire, carbon storage, water quality), iii) supporting services (necessary for maintenance of other services, 
159 i.e. habitat suitability or biodiversity, nutrient cycling), and iv) cultural (non-material benefits, e.g.

160

161

162

163 recreation, aesthetic, spiritual). Our review follows the terminology and framework provided by these reports. Table 1 summarizes the list of ES examined, and our main findings according to the sub-categorisation of provision, regulating, supporting, and cultural services, as pertaining to potential changes in these ES with respect to MPB outbreaks.

\subsection{Impact on provisioning services}

Provisioning services are perhaps the simplest to understand as these are the services that provide humans with tangible products (timber, water, food) (MEA 2005; TEEB 2010). They are also readily measured and valuated by conventional means. The current MPB outbreak has direct impacts on timber production, water supply, and non-timber forest product provisioning services.

\subsubsection{Raw materials}

\subsubsection{Timber production}

Timber provisioning has historically been a highly important ES (MEA 2005; TEEB 2010)

that is directly linked to income generation and the economic viability of many communities and nations. In the province of $\mathrm{BC}$, the current $\mathrm{MPB}$ outbreak has had a severe impact on this sector and has already killed a cumulative total of 723 million $(\mathrm{M}) \mathrm{m}^{3}$ of pine $(53 \%$ of the total merchantable pine volume) and infested 18.5 Mha of pine forests (Walton 2013); in Alberta, 25\% of the pine forest has been infested and MPB continues to expand its ranges (AESRD 2012b). The initial response of forest managers to the outbreak was sanitation harvesting (Burton 2010) and insecticide (monosodium methanearsonate (MSMA)) application (Coops et al. 2008) to mitigate infestations; efforts eventually shifted to salvage logging operations (carried out almost exclusively by clearcutting), to capture as much economic value of the resource as possible in attacked pine stands before timber value deteriorated (Burton 2010). As a result, provincial governments have increased the annual allowable cut (AAC) by $14.5 \mathrm{Mm}^{3}$ in BC (Bogdanski et al. 2011) and $\sim 3.5 \mathrm{Mm}^{3}$ in 
183 Alberta (AESRD 2012b) from the pre-outbreak AAC levels to accommodate salvage logging

184

185

186

187

188

189

190

191

192

193

194

195

196

197

198

199

200

201

202

203

204

205

206

activity. This additional supply of softwood timber is equivalent to an increase of $10.9 \%$ of Canadian and $4.0 \%$ of the North American timber supply (based on year 2000 harvest levels; Bogdanski et al. 2011). However the entire increased AAC in BC has never been met since 2007 due to the collapse of the USA housing market (Bogdanski et al. 2011), and the subsequent decrease in demand for BC timber products. Although this increased amount of AAC has provided economic benefit for a short period of time, the AAC is expected to drop in most of the MPB-affected areas once salvage logging is over. In $\mathrm{BC}$, AAC will drop approximately $12.6 \mathrm{Mm}^{3}$ below pre-outbreak levels, which will lead to a decrease of at least 20, 7.5, 4.5, and 1.5\% of BC's, Canada's, North America's and the world's softwood timber supply, respectively (Abbott et al. 2008; Bogdanski et al. 2011). This will shrink BC's timber production potential to about $\$ 774 \mathrm{M} / \mathrm{yr}$ (based on an AAC of $12.6 \mathrm{M} \mathrm{m}^{3} @$ $\$ 61.41 / \mathrm{m}^{3}$ ), including a possible decrease of $\$ 2.5 \mathrm{~B}$ in manufacturing activity, a loss of $\$ 250 \mathrm{M}$ in government stumpage (the price charged by government to companies or operators for the right to harvest timber on public land) and royalty revenues, and a loss of 27,000 jobs (Abbott et al. 2008). In Alberta, MPB-caused tree mortality likewise has some level of impact on wood industries as well as related service sectors, though detailed data are not available. Based on an assessment by Patriquin et al. (2007), BC's economy will not return to pre-MPB business as usual (e.g. forest products contributing $\sim 30 \%$ of BC's total export and $20 \%$ of the provincial revenue) until forests are fully re-established - typically 60-80 years for regeneration to a mature forest stand in $\mathrm{BC}$.

However, the scenario could be different than forecasted if salvage logging activity is carried out only where it is most beneficial (i.e., in forests that are not forecast to achieve minimum merchantable timber volumes $\left(150 \mathrm{~m}^{3} \mathrm{ha}^{-1}\right)$ based on residual understory and surviving trees after the outbreak) (Burton 2006; Coates et al. 2006, 2009; Hawkins et al. 2012; Dhar et al. 2015). Multiple field investigations have revealed that a large percentage of MPB-impacted, unsalvaged stands have 
207

208

209

210

211

212

213

214

215

216

217

218

219

220

221

222

223

224

225

226

227

228

229

230

enough residual secondary structure (seedlings, saplings, sub-canopy, and canopy trees that will survive a beetle attack) to provide minimum merchantable timber volumes $\left(150 \mathrm{~m}^{3} \mathrm{ha}^{-1}\right)$ within 30 years (Coates et al. 2006, 2009, Pousette 2010; Hawkins et al. 2012; Dhar et al. 2013; Dhar et al. 2015). Other studies have reported that only $17-25 \%$ of unsalvaged stands may need some level of management intervention to achieve target merchantable mid-term timber volumes (Coates et al. 2006; Dhar et al. 2013). In addition, surviving /residual understory and overstory tree species exhibited increased radial growth after outbreaks, although the extent of growth response varies considerably among species and sites (Axelson et al., 2009; Amoroso et al. 2013; Hawkins et al. 2013) and can be as high as $400 \%$ compared to the pre-MPB condition (Dhar et al. 2013). This implies that the recovery of timber production in most MPB-impacted, unsalvaged stands would be much faster than in the salvage-logged stands, and the money allocated for such management (plantations and land preparation expanses after salvage logging) activities can be utilized for other needed management activities, such as rehabilitating those stands that require management intervention, or to increase timber quality and volume.

\subsubsection{Food}

\subsubsection{Other forest food products}

Aside from timber harvest, a wide variety of products are collected from Canadian forests including multiple species of mushrooms, berries, herbs, and animals hunted for food and fur, etc. (Duchesne and Wetzel 2002; Mitchell et al. 2006). All these forest products are important from economic, social, cultural, and ecological viewpoints, and significantly contribute to income and employment for forest dependent communities (Duchesne and Wetzel 2002; Mitchell et al. 2006). Among these, commercial mushroom picking is one of the most important and documented income generating products in western Canadian forests (Olivotto 1999; Bravi and Chapman 2009). The pine mushroom (Tricholoma magnivelare, or Canadian matsutake, which is an ectomycorrhizal species 
231

232

233

234

235

236

237

238

239

240

241

242

243

244

245

246

247

248

249

250

251

252

253

254

that exists in a symbiotic relationship with living pine trees and is not known to produce fruiting bodies without an associated tree host) is the most economically important species of wild mushrooms in western Canada and is severely affected by the current MPB outbreak (Bravi and Chapman 2009). It has been estimated that the economic value of pine mushrooms may exceed the value of timber production over a rotation period for a unit area (Olivotto 1999; Bravi and Chapman 2009). However, salvage logging after MPB attack has detrimental effects on pine mushroom habitat due to soil disturbance and reduced availability of living host trees (Bravi and Chapman 2009), leading to a longer recovery period compared to unsalvaged conditions in which pine mushroom habitat can be re-established within 15 years of infestation (Bravi and Chapman 2009).

In general, there is little understanding of how different forest foods and products (berries, herbs or animals hunted for food and fur) have been impacted by the current MPB outbreak.

However, numerous studies find a negative relationship between forest fruit production and canopy closure. This relationship is most commonly discussed in relation to grizzly bear food sources in post-fire stands and post-harvest cutblocks (e.g. Nielsen et al. 2004), and is therefore not equivalent to human food collection / fruit picking in post-MPB infested stands. Nevertheless, it deserves highlighting that higher fruit production in disturbed stands can be explained by the positive relationship between fruit production and direct, incoming photosynthetically active radiation (Parks Canada 2001). Hamer (1996) found that forest canopy cover accounted for $70 \%$ of the variation in buffaloberry fruit production. Moola and Mallik (1998) find that reproductive performance of V. myrtilloides (blueberry) was greatest under partial shade conditions, but recognise the site-specific conditions, in that blueberry production is limited by shading from regenerating hardwoods, and from mechanical damage to above-ground biomass associated with clearcutting. Finally, Larsen (2102) finds that fruit production declines precipitously in cutblocks after about 20 years because of canopy closure, and Stone and Wolfe (1996) report that frequency of fruit occurrence is positively 
255 related to increasing tree mortality, but is highly variable. The response of food provisioning ES are

256

257 therefore mixed, and further detailed studies are recommended to ascertain the degree of impact on this ES sector.

\subsubsection{Water provisioning}

Forests in western Canada play a vital role in the terrestrial hydrological cycle by contributing to water provisioning (water yield), regulation (the seasonal distribution of flows), purification (quality), and aquatic habit ES; the latter two are discussed in the next section on regulating and supporting services. The current MPB outbreak combined with large scale salvage logging has complex interactions among the different hydrological processes (i.e. evapotranspiration, local meteorology, snow accumulation, ablation, etc.) resulting in a) increased snow accumulation and earlier and more rapid spring melt (Boon 2007; Embrey et al. 2012); b) decreased evapotranspiration (Hélie et al. 2005; Embrey et al. 2012); c) decreased channel roughness due to large, woody debris removal leading to decreased flow attenuation (Bunnell et al. 2011); and, d) extension of the channel network by roads, thereby increasing the drainage network and water delivery routes (Bunnell et al. 2011). Thus, MPB-caused tree mortality and logging activities have potential effects on water yield during the spring and early summer as well as in the late summer (Wong 2008), which may increase the possibility of early season freshet, drier soils in the late summer, and water shortages at higher elevations and in late summer. Using a paired-watershed analysis in a $30 \%$ clear-cut (salvage logged) of the total MPB infested area in southern BC, Cheng (1989) found that annual water yields and peak flows increased by $21 \%$ with a 13 -day advancement of peak flows in the spring. Similar results have also been reported in Montana (15\%, and 14-21 days) (Potts 1984). Other studies (Stednick 2007; BC Forest Practices Board 2007; Schnorbus 2011) have shown that MPB-caused mortality has a smaller impact on peak water flow compared to the cumulative effect of MPB and salvage logging. Post-beetle forest management by salvage logging 
279

280

281

282

283

284

285

286

287

288

289

290

291

292

293

294

295

296

297

298

299

300

301

302

may thus require extra caution, particularly in community watersheds, to minimize the impact on watershed ecosystem functions.

\subsection{Impact on regulating services}

Regulating services maintain essential ecosystem processes for human well-being and control rates of other services for stabilizing the supply of ES (MEA 2005; TEEB 2010). Disruption of any regulating service may threaten the sustainability of other essential ES. MPB-caused mortality has direct and indirect negative impacts on certain regulating services.

\section{2.1. Sediments and water purification: Regulating services affecting water quality}

Changing water quality affects many aspects of human well-being, and benefits or costs accrue to different groups of beneficiaries at varying spatial and temporal scales. Water quality is, therefore, an important regulatory ES that also contributes to other services including recreation and human health (MEA 2005; TEEB 2010). Forest ecosystems with intact groundcover and root systems are very effective at regulating water flow and improving water quality. The current MPB outbreak has changed forest structure, including the water and energy cycles that may potentially alter solute transport and hence, water quality (Mikkelson et al. 2013). The overall impact on water quality is most likely greatest in areas that have been salvaged (Larkin et al. 1998; Wong 2008; Brown and Schreier 2009). Several studies reported that road density and the frequency of stream crossings increase during salvage logging, which, combined with potentially higher flows, leads to increased erosion and degradation of water quality by adding sediment, carbon, free radicals $\left(\mathrm{NO}_{3}\right)$, and minerals to water (Larkin et al. 1998; Mann et al. 2007; Stednick 2007; Wong 2008; Brown and Schreier 2009; Clow et al. 2011 Mikkelson et al. 2013). Based on expert opinion, sediments provide surfaces for micro-organisms like Escherichia coli (Migula.) and Giardia spp. to breed, which increases the risk of people suffering from water-borne illnesses (Wong 2008) as well as increasing the water turbidity, leading to increased gastrointestinal illness (Mann et al. 2007). Similarly, 
303

304

305

306

307

308

309

310

311

312

313

314

315

316

317

318

319

320

321

322

323

324

325

326

changes in organic carbon loading in the source water are very harmful for humans due to the production of carcinogenic disinfection by-products (DBP) during water purification with chlorine (Mikkelson et al. 2013). Based on a study in Colorado, an average of 300\% more organic carbon and DBP was observed at water treatment facilities located in MPB-infested unsalvage logged watersheds (Mikkelson et al. 2012). Considering other minerals, Brown and Schreier (2009) observed that total aluminum (Al) and other trace minerals' ionic concentrations showed significant increases during peak flow and decreases in low flow, while an opposite trend was observed for calcium $(\mathrm{Ca})$, magnesium $(\mathrm{Mg})$, and other soluble mineral or salt concentrations. These changes can necessitate increased water purification before human consumption.

\subsubsection{Extreme events: Forest fire regulation}

The current MPB outbreak may also influence regulating services including forest fires, thus impacting human society in different ways (Mikkelson et al. 2012). In addition to timber loss, forest fires release particulates, carbon monoxide and carbon dioxide, and nitrogen oxides to the atmosphere, leading to decreased air quality that is directly linked to human health hazards and the economy (Mikkelson et al. 2012). In western Canada, forest fires and MPB outbreaks have increased in extent and severity during recent decades (Perrakis et al. 2014), thus raising concerns about their possible interactions (Negron et al. 2008). Generally, it is hypothesized that MPB-induced tree mortality affects fire behavior by altering the flammability, continuity, and structure of fuels (Lynch et al. 2006; Jenkins et al. 2008; Hicke et al. 2012a; Jenkins et al. 2014). Moreover, the profiles of surface, ladder, and crown fuels are expected to change with time since outbreak, potentially altering fire behavior and fire risk (Jolly et al. 2012; Jenkins et al. 2014). After tree death, needles fade to red within a year of attack (red stage) and risks of ignition, torching, and canopy fire are expected to increase in this initial stage post-attack due to lower leaf moisture content (10 times lower in foliar moisture content compared to green needles), and greater percentage content of non-fibre 
327 carbohydrates and fats, which increase flammability (Jolly et al. 2012; Page et al. 2012). Some

328

329

330

331

332

studies indicated that during the red stage, a high probability of active crown fire may occur (Page

and Jenkins 2007; Hoffman 2011) while others predicted that passive fire (surface fire with torching

of individual crowns), rather than active crown fire through the canopy, was more probable during

this red stage (Simard et al. 2011; Klutsch et al. 2006). Approximately 3 to 10 years (gray stage)

after the beetle attack, trees drop their needles and twigs and become exposed in the upper crown

(Hicke et al. 2012a) which likely increases the forest floor fuels (Hicke et al. 2012a; Jenkins et al.

2014). Therefore, it is expected that surface fire will be more likely to spread into the canopy during

the gray stage (Collins et al. 2012). However, empirical studies have revealed mixed results; some

studies report that MPB impact increases forest fire frequency and intensity (Lotan et al., 1985;

Romme et al., 1986; Lynch et al., 2006; Jenkins et al. 2014; Perrakis et al. 2014) while others found

no evidence of any relationship (Klutsch et al. 2011; Schoennagel et al. 2012; Bourbonnais et al.

2014; Harvey et al. 2014; Hart et al. 2015; Meigs et al. 2015) or concluded that there is a reduction in the probability of active crown fire in the short term by thinning lodgepole pine canopies (Alfaro et al. 2010; Simard et al. 2011). Other studies emphasize that climate has more effect than MPB outbreaks on the fire regime, with fire dynamics being driven primarily by weather conditions (i.e., extremely dry and gusty with a sustainable ignition event) and topography (Kulakowski and Jarvis 2011; Klutsch et al. 2011; Schoennagel et al. 2012; Harvey et al. 2014). These contrasting results suggest that MPB and its impacts on fuel accumulation and subsequent fire hazard are likely sitespecific, change over time post-infestation, and are inter-related with a number of other important environmental variables. Thus, the ongoing debate about how important outbreaks actually are to fire risk, relative to the potentially overriding influence of climate and weather on the fire regime, still persists.

\subsubsection{Climate regulation: Carbon storage}


351 Carbon sequestration is an important regulating ES related to greenhouse gas (GHG)

352 regulation (MEA 2005; TEEB 2010; Lal et al. 2013). The current MPB outbreak is expected to have

353 a direct influence on carbon dynamics because tree mortality may reduce the rate of forest carbon

354 uptake and increase future emissions through decomposition of dead trees (Kurz et al. 2008;

355 Caldwell 2012; Hicke et al. 2012b). However, the net impact on carbon cycling is in debate, as

356 different research approaches and studies have yielded different results (Foley et al. 2005; Kurz et al.

357 2008; Brown et al. 2010; Mathys et al. 2013; Emmel et al. 2014; Hansen et al. 2015). Based on

358 modelled projections, Kurz et al. (2008) reported that the cumulative impact of the MPB outbreak

359 during 2000-2020 will be 270 megatonnes (Mt) of carbon or $990 \mathrm{Mt}$ of carbon dioxide equivalent

$360\left(\mathrm{CO}_{2} \mathrm{e}\right)$ greenhouse gases $(\mathrm{GHG})$, which is comparable to 6 years of emissions $\left(166 \mathrm{Mt} \mathrm{CO}_{2} \mathrm{e}\right.$ in

361

2010) from Canada's transportation sector or 10 years of emissions from the electrical sector (99 Mt

$362 \mathrm{CO}_{2} \mathrm{e}$ in 2010) (Environment Canada 2012). The total expected monetary value of GHG would be

363 equivalent to \$30.94 B (US dollar conversion in October 2015 @ 1.25 CA \$) by 2020 based on the

364 current price of carbon set by the International Monetary Fund (US\$25 per ton) (Litterman 2013).

365 This suggests that vast tracts of forests are converting from a net $\mathrm{C}$ sink to a net $\mathrm{C}$ source, which

366 affects carbon dynamics and will exacerbate global climate change (Foley et al. 2005). However, in

367 contrast to this modelling projection, in a recent study Arora et al. (2016) reported that the current

368 MPB outbreak results in BC's forests accumulating $328 \mathrm{Mt}$ less carbon over the period of 1999-2020

369 while during this same period changing climate and increasing atmospheric $\mathrm{CO}_{2}$ concentration yields

370 an enhanced carbon uptake equal to a cumulative sink of around $900-1060 \mathrm{Mt} \mathrm{C}$ which is almost

371 three times higher than the total loss. Similarly, field measurements from eddy flux towers in MPB-

372 impacted stands suggest forests are not changing from a net $\mathrm{C}$ sink to a net $\mathrm{C}$ source, since $\mathrm{CO}_{2}$

373 uptake and water use efficiency (ratio of ecosystem $\mathrm{C}$ gain to evapotranspiration) did not change

374 during the MPB outbreak compared with undisturbed forests (Reed et al. 2014). Other flux tower 
375 studies also reported that retaining healthy residual stems in the MPB-impacted forest results in

376 higher $\mathrm{C}$ sequestration due to the rapidly regenerating undergrowth (growing season $\mathrm{C}$ sink)

377 compared to clear cut stands (C source) (Brown et al. 2010; Mathys et al. 2013; Emmel et al. 2014).

378 A comparable result was also reported in a growth and yield modelling study by Hansen et al. (2015)

379 for the Central US Rockies. Likewise, other field-based growth dynamics studies in BC also

380 conclude that in post-beetle conditions the residual overstory and understory show increased radial

381 growth compared to pre-MPB conditions (Coates et al. 2009; Amoroso et al. 2013; Hawkins et al

382 2013, Dhar et al. 2013). This indicates a higher carbon uptake by the residual tree species in post-

383 beetle stands (Hansen 2014). Therefore, it is likely that MPB impacts on forest carbon are lower than

384 originally predicted and in some cases MPB-caused mortality can stimulate stand growth and

385 productivity (Kimmins 1987). However, this underscores the importance of maintaining healthy

386 residual forest overstory and understory in MPB-affected areas, and suggests that some management

387 actions can be taken to sustain residual forest health as healthy forests can accumulate and sequester

388 large amounts of carbon from the atmosphere (Fettig et al. 2013a).

389

390

391

392

393

394

395

396

397

398

\subsection{Impact on supporting services}

Supporting services are those that are needed for the production of all other ES (MEA 2005).

These kinds of services (i.e. habitat suitability, nutrient cycling) differ from other categories of ES as their impacts on society are either indirect or occur over a very long time (MEA 2005)).

\subsubsection{Habitat suitability or biodiversity}

\subsubsection{Terrestrial habitat}

In most cases MPB outbreak emulates a thinning from above, which allows more growing space (light, water, nutrients, etc.) for surviving residual individuals and promotes growth (Dhar and Hawkins 2011). The current MPB outbreak has thus resulted in increased species richness and diversity for understory and herbaceous flora and fauna, although responses are highly variable 
399 (Kovacic et al. 1985; Stone and Wolfe 1996; Amoroso et al. 2013; Pec et al. 2015; Edwards et al. 400 2015; Perovich and Sibold 2016). Based on a recent study in western Alberta, Pec et al. (2015) 401 reported that understory community diversity and productivity increased with the increase of tree 402 mortality. Similar observations were also reported in lodgepole pine stands, northern Utah (Stone 403 and Wolfe 1996) and in ponderosa pine (Pinus ponderosa Douglas ex C. Lawson) stands, eastern 404 Colorado (Kovacic et al. 1985). According to Kovacic et al. (1985) understory biomass increased by $40550 \%$ five years following beetle attack in ponderosa pine stands. In another study Perovich and 406 Sibold (2016) reported that MPB outbreak initiated a shift in forest structure from single-cohort 407 lodgepole pine stands to stands with greater diversity in age classes and species composition. 408 Conversely, MPB-caused mortality may have a negative impact on certain bryophytes and lichens as 409 they require a more shaded habitat (Cichowski and Haeussler 2013), whereas light loving ground 410 lichen (Cladina spp., Cladonia spp., Cetraria spp.) may experience less impact. However, further 411 study regarding the response in bryophytes and lichens are required to fill this knowledge gap.

412 Nonetheless, the majority of studies conclude that the occurrence of MPB attacks in most of the pine 413 dominated stands results in more structurally and compositionally diverse stands, leading to multiple 414 successional pathways different from those developed after logging or fire (Axelson et al., 2009;

415 Dhar and Hawkins 2011; Hawkins et al., 2012; Amoroso et al. 2013; Dhar et al. 2015). Considering 416 the species composition, MPB-attacked forests are undergoing substantial conversion-moving from

417 lodgepole pine to more shade-tolerant species subalpine fir (Abies lasiocarpa Hook. Nutt.) and 418 white spruce and their hybrid (Picea glauca Moench Voss $\times$ Picea engelmannii Parry) followed by 419 low-to-moderate shade tolerant species such as lodgepole pine and Douglas-fir (Pseudotsuga 420 menziesii (Mirb.) Franco) (Axelson et al. 2009; Dhar and Hawkins 2011; Hawkins et al. 2012; 421 Amoroso et al. 2013; Perovich and Sibold 2016). 
For wildlife species, MPB outbreaks may have either direct (altering food availability),

423

424

425

426

427

428

429

430

431

432

433

434

435

436

437

438

439

440

441

442

443

444

indirect (altering habitat suitability), or mixed impacts (Chan-McLeod 2006; Martin et al. 2006; Saab et al. 2014). Without salvage logging, MPB-caused mortality potentially benefits about $65 \%$ of the resident terrestrial vertebrate fauna, while salvage logging is anticipated to have negative effects on at least 35\% of a total of 182 (127 birds, 50 mammals; four amphibians and one reptile based on three major MPB impacted forest districts) species inventoried in the ecosystem (Bunnell et al. 2004). The cavity-nesting species (e.g black-backed woodpecker (Picoides arcticus S.)) responded more favorably to beetle-impacted forests than species with open-cup nests, as dead pine trees provide both food and nesting sites (Bonnot et al. 2008; Saab et al. 2014). Wildlife species that depend on the forest cover, however, showed negative responses (Bonnot et al. 2008). Mammalian species such as red squirrels (Tamiasciurus hudsonicus Erxleben) showed both negative (Drever and Martin 2007; Steventon 2015) and neutral (e.g. when non-host tree species are present) responses (Saab et al. 2014), while a negative response was found for small mammals in salvaged logged stands (Sullivan et al. 2010). However, when the stand opens up due to the fall-down of snags, significant beneficial effects accrue to wildlife as the forest structure changes to multi-layered canopies with diverse classes and sizes of tree species (Chan-McLeod 2006; Saab et al. 2014). The MPB impact on species at risk, such as woodland caribou (Rangifer tarandus caribou Gmelin), may be minimal because despite the decrease in terrestrial lichen (species that woodland caribou prefers to eat) abundance and potential changes in snow conditions due to needle loss in pine forests, caribou still continue to crater for terrestrial lichens in matured killed pine stands (Cichowski 2010; Seip and Jones 2010). However, further study is required to validate MPB impact on caribou populations and their habitats. Although we have some level of understanding about the response of wildlife to MPB outbreaks, a significant knowledge gap still persists; therefore, detailed 
445

and long term studies across different geographic locations are needed with emphasis on how different endangered or species at risk respond to MPB outbreak.

\subsubsection{Aquatic habitat}

Commercial and sport fishing play an important role in Canada's national and regional economies and are highly dependent on freshwater habitats that serve as spawning and rearing grounds for many species of fish, including salmon (Zwickel 2012; Bailey and Sumaila 2013). The approximate cumulative value of current freshwater commercial fish production (BC: $\$ 445.4 \mathrm{M}$; Alberta: $\$ 10 \mathrm{M}$ ) and sports fishing (BC: $\$ 957 \mathrm{M}$; Alberta: $\$ 488.1 \mathrm{M}$ ) is around \$ $2 \mathrm{~B} / \mathrm{yr}$ (Alberta Agriculture, Food and Rural Development 2006; Statistics Canada 2012; Zwickel 2012; Bailey and Sumaila 2013). Based on a study in central BC, a total of 29 freshwater fish species are found and one quarter of these (e.g. Bull trout (Salvelinus confluentus S.), salmon (Oncorhynchus spp etc.)) are potentially (negatively) impacted by the combined effects of MPB and salvage logging; among these species, salmon would be the most severely impacted (Johannes et al. 2007). From the different studies it is evident that MPB outbreak in combination with large scale salvage logging severely affects the forest watershed and its related aquatic environment (Bunnell et al. 2004, 2011); alteration of the aquatic environment by increased water flow, sedimentation, and temperature has direct negative effects on fish life cycles, and subsequently fish production (Larkin et al. 1998; Wong 2008). Higher sedimentation could be lethal for resident and migratory fish populations present in the streams (Wong 2008; Bunnell et al. 2011). Although an MPB outbreak has minimal impact on water temperature [as grey-attack stands had higher shade values than harvested sites (see Forest Practise Board 2007; Rex et al. 2009)], salvage logging from riparian areas after MPB attack could increase average water temperature by up to $1.5^{\circ} \mathrm{C}$ in larger streams (river or canal) (Maloney 2004) and up to a maximum of $16^{\circ} \mathrm{C}$ with an average of $10^{\circ} \mathrm{C}$ in small and shallow streams (Bunnell et al. 2004). As well, these temperature changes can persist over long periods, up to 10-15 years (Johnson 
and Jones 2000). Increases in water temperature can cause growth inhibition, reduced survivability, increased susceptibility to disease, and alteration of fish egg and juvenile development (Ferrari et al., 2007; Johannes et al., 2007; Wong 2008). The physiology of migratory fish like salmon and their egg development are directly impacted by higher water temperatures. Adult salmon cease feeding when they begin their migration from marine to fresh water, and rely on their stored up energy to return to their spawning grounds (Rand et al. 2006), but in high water temperatures their metabolic rate is accelerated, which causes early death (before spawning) (Ferrari et al. 2007).

Large woody debris (LWD) in streams is also critical for habitat formation; after a MPB attack, more large woody debris is imported into stream channels if no salvage logging operation is carried out. According to Hassan et al. (2008), in cases of $100 \%$ pine mortality, input rates of LWD in the stream may increase up to 3.7 times over pre-outbreak rates, ranging from 2.45 to $47.1 \times 10^{-5}$ $\mathrm{m}^{3} / \mathrm{m}^{2} / \mathrm{yr}$. This may lead to development of relatively frequent and impermeable log jams, where riffles that serve as spawning areas (especially for salmon and trout (Salmo spp)) are either buried or eroded, rearing pools are filled, and egg incubation environments are smothered with fine, textured sediments (Bission et al. 1987). Any detrimental effects on salmon may have severe implications for the commercial fishing industry and fish-dependent communities, especially First Nations groups, as salmon has been a significant part of their culture and economy for thousands of years. On the other hand, LWD could provide breaks in the water current that serve as foraging sites for fish feeding on drifting food items and also form eddies where food organisms are concentrated. LWD also provides cover for Bull trout as they require cool water for their physiological development (Hinch and Mellina 2008). However, further studies on responses of different fish species to MPB outbreaks may be required for better documentation. In addition to documented cascading impacts of MPB and subsequent salvage logging operations on fish habitats, this study also suggests that forest 
492

493

494

495

496

497

498

499

500

501

502

503

504

505

506

507

508

509

510

511

512

513

514

515

management by salvage logging should be restricted in riparian zones and limited in other areas of watersheds containing both fish bearing and non-fish bearing streams and lakes.

\subsubsection{Nutrient cycling}

Nutrient cycling is a key ES that contributes to supporting life on earth (MEA 2005).

Generally, mineral nutrients from the soil are absorbed by trees as they grow, accumulate in their bodies, and are released when they die (Xue and Tisdell 2001). High tree mortality due to MPB attack can alter the nutrient cycling (nitrogen, phosphorus, organic carbon, metals, and base cations) process in the soil (Mikkelson et al. 2013; Trahan et al. 2015). As trees begin to die following a beetle attack, nitrogen $(\mathrm{N})$ uptake slows down and eventually ceases, which can lead to excessive nitrogen pools (increase in the rate of net $\mathrm{N}$ mineralization and nitrification) in the underlying soil until vegetation regrowth compensates (Griffin et al. 2011; Mikkelson et al. 2013; Cigan et al. 2015). Moreover, increased litter from the dead trees (Clow et al. 2011; Griffin et al. 2011; Cigan et al. 2015) can also increase inorganic nitrogen pools in the soil (Cullings et al. 2003). Transformation processes such as nitrification/denitrification and mineralization could be enhanced due to an abrupt increase in carbon sources, soil moisture, and microbial activity from higher energy fluxes in the ground (Mikkelson et al. 2013). However, confounding factors such as catchment nitrogen deposition, surviving vegetation, and climate can lead to different responses post-beetle infestation (Mikkelson et al. 2013). Phosphorus (P) flux, either in the form of dissolved phosphate or particulate P has the potential to be altered after a MPB attack as phosphate is readily released from decaying organic matter (Mikkelson et al. 2013). The MPB outbreak could also influence dissolved organic carbon (DOC) concentrations as decreases in canopy cover can increase runoff rates, and excess needle loss onto the forest floor compounded by soil moisture and temperature leads to increased decomposition and soil organic matter leaching (Mikkelson et al. 2013; Trahan et al. 2015).

According to Trahan et al. (2015), dissolved organic carbon (DOC), dissolved organic nitrogen 
516 (DON), and inorganic phosphorus $\left(\mathrm{PO}_{4}{ }^{3-}\right)$ concentrations in the soil decline up to 45-51, 31-42, and

517

518

519

520

521

522

523

524

525

526

527

528

529

530

531

532

533

534

535

536

537

538

539

53-55\% respectively within 4 years after MPB attack, but in 5-6 years after an attack DOC, DON, and $\mathrm{PO}_{4}{ }^{3-}$ recovered to $71-140 \%$ of those measured in undisturbed plots. In another study, Clow et al. (2011) observed no significant changes in stream-water $\mathrm{NO}_{3}$ or DOC, however, total $\mathrm{N}$ and $\mathrm{P}$ increased. Interestingly, Griffin et al. (2011) and Keville et al. (2013) concluded that, although MPB outbreaks significantly altered the $\mathrm{N}$ cycling, the net effects were surprisingly minor given the extent of the beetle-caused mortality. Conversely, MPB outbreaks may also influence cation and aluminum fluxes as increased nitrification reduces the soil $\mathrm{pH}$ and leads to the exchange and loss of base cations $\left(\mathrm{Ca}^{2+}, \mathrm{K}^{+}, \mathrm{Mg}^{2+}\right)$; however further studies are required to confirm these changes. Based on the above discussion it can be suggested that MPB outbreaks may have short-term impacts on nutrient cycling but long-term monitoring may be required to determine whether biogeochemical changes are indeed more subtle in MPB-impacted pine ecosystems.

\subsection{Impact on cultural services}

Cultural ES are more difficult to define and measure as they are tightly bound to human values, behaviour, and socioeconomic conditions, which may differ widely across groups of people and even amongst individuals (MEA 2005; TEEB, 2010). Cultural ES are most commonly defined as those services which enhance emotional, physical, and cognitive wellbeing for people (Farber et al. 2006). In this section, the impact of the MPB outbreak on cultural services is presented in light of tourism and recreation, and aesthetic (visual or scenic beauty) services.

\subsubsection{Tourism and recreation}

Tourism and recreation is an ES defined as the "recreational pleasure people derive from natural or cultivated ecosystems" (MEA 2005; TEEB 2010). This service is a very important revenue generating ES sector that is rapidly expanding with the increase of human mobilization, and it plays a significant role in western Canada's economy. The average estimated direct earnings by the 
540 government from recreational sites was \$35.3 M (\$17.7 M in BC and 17.6M in Alberta) in 2012 (BC

541 Ministry of Environment 2013; Alberta Tourism, Parks and Recreation 2014). Other than direct

542 revenue, users of forests and recreational sites are also contributing to different regional, socio-

543 economic sectors (i.e., job creation, local business, etc.). This service sector contributed

544 approximately $\$ 392 \mathrm{M}$ and over 5,200 full-time jobs in 2012-2013 in BC (BC Ministry of

545 Environment 2013). In addition to having direct economic benefits to the province, users of

546 recreation sites benefit in non-tangible ways through stress reduction, increased physical fitness, and

547 overall well-being, and thus lead to reductions of $\$ 4.4 \mathrm{M}$ to $\$ 6.7 \mathrm{M}$ in healthcare costs annually (BC

548 Ministry of Forests, Lands and Natural Resource Operations 2012).

549 There are 2,275 recreational sites or provincial parks in $\mathrm{BC}$ and Alberta $(1,319$ in $\mathrm{BC}$ and

1,258 in Alberta) and 1,151 designated recreation trails (818 in BC and 333 in Alberta) with an

average of $20.8 \mathrm{M}$ visitors each year. The current MPB outbreak has affected almost $80 \%$ of

552

recreation sites and trails in the Central Interior of BC (BC Ministry of Forests, Lands and Natural

Resource Operations 2012), while in Alberta the effect is not as severe. However, with one exception

554 (Kootenay National Park), none of the park campgrounds or trails were closed in BC after the

outbreak has neither extensively, nor negatively, impacted local recreational activity in impacted

areas in BC (Michael et al. 2011), and at the same time visitor use has expanded by 5.5-7.5\% during

the outbreak period (BC Ministry of Environment 2008, 2013). Conversely, negative impressions

expressed by recreational users were reported in MPB-infested Banff and Kootenay national parks

(McFarlane et al. 2006; McFarlane and Watson 2008) in Canada. In another study, Rosenberger et al.

561 (2013) mentioned that MPB outbreaks result in significant losses in recreation values, at least in the

562 short term, while moderate to severe MPB outbreaks can cause losses in total recreation values from

$563 \$ 5 \mathrm{M}$ to $\$ 59 \mathrm{M}$, and may reduce recreation visitation by $0.5 \mathrm{M}$ user days at maximum outbreak levels 
564

565

566

567

568

569

570

571

572

573

574

575

576

577

578

579

580

581

582

583

584

585

586

587

in Rocky Mountain National Park, USA (Rosenberger et al. 2013). However, when we look at the overall visitation and revenue of Kootenay National Park in Canada from 2005-2010 (daily entrance and camping attendance), there was an increase from 1.34 to $1.42 \mathrm{M}$ tourists and $\$ 1.33$ to $\$ 1.77 \mathrm{M}$ during the peak MPB attack season, respectively (BC Ministry of Environment 2010). This implies that although tourists' attitude toward beetle impact may have been negative (McFarlane et al. 2006; McFarlane and Watson 2008), overall visitation and revenue earnings were not affected by MPB in Canadian national parks. The overall impact of MPB outbreak on tourism and recreation revenue and visitor numbers, as well as on the visitor experience, thus seems to have been minimal.

\subsubsection{Aesthetic/visual/scenic beauty}

Aesthetic value is an ES that relates to people's appreciation of natural scenery in ways other than through deliberate recreational activities (TEEB 2010). Aesthetic appreciation of forest land, and urban, rural, or coastal landscapes is one of the most fundamental ways that people may experience and relate to their physical environment. Sometimes called visual quality, scenic beauty of the environment is a well-recognised and accepted dimension of aesthetic appreciation. Insect outbreaks produce a wide range of visual effects depending on the forest type, the specific insect, geographic location, and many other factors including temporal stage and biophysical condition (Rosenberger and Smith 1998; Sheppard and Picard 2006). Generally, after a MPB attack, the colour of the trees goes through three stages: a) green stage, in the first year after an attack; b) red stage, up to 4 years after attack when foliage turns brownish and then red; and c) grey stage, more than 4 years after an attack when the dead tree has lost its needles. The remaining gray boles provide the predominant visual effect until forest regeneration and recovery occurs, which can often take 20-30 years (BC Ministry of Forest 1994). Most studies clearly document that MPB-caused mortality negatively affects the visual quality of the forests (Buhyoff et al., 1982; Daniel et al. 1991;

Rosenberger and Smith 1998; Sheppard and Picard 2006; BC Ministry of Forests and Range 2010; 
588 Meitner et al. 2011) and consequences could be more dramatic at high levels of attack (Daniel et al. 589 1991; Sheppard and Picard 2006). Based on a survey in six MPB-impacted communities in BC, 590 Meitner et al. (2011) reported that most of the respondents were deeply concerned about the visual 591 impact on the forest although their recreational activity during the infestation was more or less the 592 same as before. Although MPB has significant impact on the scenic beauty public perceptions appear 593 to be complex, and poorly understood.

\section{4. Management of MPB outbreaks}

595 In western Canada, MPB management was first initiated when lodgepole pine timber value 596 grew in the early twentieth century. The initial response was to destroy the beetle through direct 597 control (cruising, decking and burning) (Hopping and Mathers 1945). However, with the 598 1974). Since then, research has increasingly focused on developing decision support tools, such as 601 hazard- and risk-rating systems for stands susceptible to beetle attacks (Amman et al. 1977; Amman 602 and Anhold 1989; Shore and Safranyik 1992; Shore and Safranyik 2004). Attention has thus 603 gradually shifted from reactive (direct control) to proactive (preventive) MPB management. Over the 604 past two decades, considerable research effort has focused on development of landscape-level 605 models (Riel et al. 2004) to predict patterns of mountain pine beetle outbreak development, 606 607 comparing potential outcomes of control strategies, and project impacts on forest management objectives (Fall et al. 2004). In spite of significant advancement in MPB management, none of this knowledge can solely mitigate the problem and management still depends on sanitation harvesting to control infestations by removing infested trees, use of prescribe fire, insecticides (MSMA), semiochemicals, or pheromones used on trap trees (Coops et al. 2008; Fettig et al. 2014; Gillette et 611 al. 2014). Unfortunately, the effectiveness of some of these direct management approaches 
612 (sanitation, insecticide, semiochemicals) won't last more than 2 years, some have a negative effect

613 on the environment (insecticide), and some require higher cost, skills, and labour (sanitation,

614 prescribed fire) to implement (Fettig et al. 2007; Coops et al. 2008; Wulder 2009; Fettig et al. 2013b;

615 Gillette et al. 2014; Progar et al. 2014). On the other hand, some researchers suggest indirect

616 management or pre-emptive logging in advance of beetle infestation, such as thinning from below,

617 tree crown thinning, and selection thinning treatments (Dahlsten and Rowney 1983; Mitchell et

618 al.1983; Fettig et al. 2007). Most of these indirect approaches may effectively control the beetle for

$61920-30$ years at the initial stage of beetle spread; however, such approaches are more labour intensive

620 and may require a huge financial investment to carry out at the field level and need to be applied

621 before beetle outbreaks (Dahlsten and Rowney 1983; Mitchell et al.1983; Fettig et al. 2007; Coops et

622 al. 2008). In the context of western Canada, these approaches may be suitable at the beginning of a

623 MPB infestation or a small scale attack, but in cases of outbreak infestation none of these approaches

624 would be effective or suitable due to the large extent of pine forests ( $>25 \mathrm{M}$ ha), the lack of

625 manpower to implement, inaccessibility to many beetle-impacted areas, economic constraints, and

626 the large spatial extent of the beetle population. Therefore, management of MPB outbreaks should be

627 diverted to a post-beetle, stand management strategy by a) using salvage logging to reduce the

628 economic impact (to recover the value of dead standing timber) of a beetle outbreak, and b) facilitate

629 stand re-establishment where needed (Burton 2010; Dhar et al. 2015). While these management

630 interventions are generally carried out within the constraints of government regulations that require

631 some protection of wildlife habitat and riparian areas, their principal purpose is to protect and

632 recover standing timber for commercial interests. Given the large spatial extent of MPB outbreaks,

633 the potential landscape and ecosystem-scale impacts of timber-based management approaches to

634 control and mitigate the effects of infestations are significant over decadal timescales. We argue that

635 management of MPB-impacted forests should take a systems level approach that considers the 
636 multiple interacting processes in a forest necessary for the maintenance of a wide range of 637 supporting, provisioning, and regulating ES.

638 As this review has shown, large scale salvage logging may have significant negative effects 639 on multiple forest ES including timber production, biodiversity, water quality and provisioning, 640 aesthetic or scenic beauty, and aquatic habitats (Dhar and Parrott 2015). The clearcut logging 641 practices widely used throughout the region (for salvage or pre-emptive harvesting in response to the 642 MPB outbreak) create a homogenous, even-aged landscape structure that undermines many ES, has 643 negative impacts on biological diversity, and may impair ecosystem recovery and resilience due, in 644 part, to the maladaptation of some species to the interactive effects of two disturbance events (MPB 645 and logging) (Lindenmayer et al. 2008; Burton 2010; Dhar and Hawkins 2011; Dhar and Parrott 646 2015; Dhar et al. 2015). Such homogenous, even-aged stands would be more susceptible to future natural disturbances like MPB and fire. Conversely, if MPB-impacted stands were left untreated or unsalvaged, most of the stands in western Canada would convert into a heterogeneous landscape structure where mosaics of even-aged and uneven-aged patches are interspersed in space (Agee 1993; Burton 2010; Dhar and Hawkins 2011; Amoroso et al. 2013; Gillette et al. 2014; Dhar et al. 2015). The ES provisioning in these heterogeneous forests can recover faster from MPB impacts than the salvage logged stands, as a significant portion of biological legacies (i.e. surviving trees, 653 snags and logs, patches of intact vegetation, and seedbanks in tree crown or in the soil) of that particular ecosystem remain intact (Gustafsson et al. 2012; Lindenmayer et al. 2012; Fedrowitz et al. 2014; Dhar et al. 2015). This allows the forest to "remember" its genetic, compositional, and structural pre-harvest condition, contributing to regeneration of a new complex ecosystem (Drever et al. 2006; Dhar et al. 2015). This ecosystem memory is likely an important factor necessary for maintaining resilience of MPB impacted stands. All evidence suggests that unsalvaged stands are more resilient than salvaged stands and can maintain the identity, structure, and function of an 
660

661

662

663

664

665

666

667

668

669

670

671

672

673

674

675

676

677 Provisioning services:

678

679

680

681

\section{Conclusions}

Regulating services: ecosystem after disturbance, as well as significantly reducing susceptibility to future MPB infestation (Drever et al. 2006; Lindenmayer et al. 2008; Schowalter 2012; Dhar and Parrott 2015; Dhar et al. 2015). In addition, accelerated timber harvesting has significant negative impacts on different ES by influencing the ecosystem processes and related biota. Thus, from a whole systems perspective in which maintenance of a range of ES is a management objective, salvage logging to accelerate shortterm timber volumes may not always be the best post-beetle management response. Research suggests that the large number of residual green trees that have survived the beetle outbreak in MPBaffected forests may provide valuable mid-term timber volumes, habitat, and ecosystem benefits when they are most needed after a beetle outbreak (Burton 2010; Six et al. 2014; Dhar et al. 2015).

Our argument here is not to forego management, but rather that management should be led by science and monitoring where socio-ecological considerations, the best available data, local and expert knowledge, professional judgment, and long term cost benefit assessments (based on a range of ES beyond timber production) need to be considered.

The current MPB outbreak in western Canada affects different ES both positively and negatively. From a critical analysis of the current literature, the following generalization statements about the MPB-infested forests in western Canada can be made, although knowledge gaps persist:

- Timber production is the most severely affected ES, followed by water supply and food (berries and pine mushroom). Impacts on these services may directly contribute to economic crises and social cohesion in forest-dependent communities. 
682

683

684

685

686

687

688

689

690

691

692

693

694

695

696

697

698

699

700

701

702

703

704

705

- Water quality is the most severely impacted regulating ES, while debate persists regarding the impact of MPB outbreaks on forest fire regulation and carbon dynamics or climate stabilization.

Supporting services:

- Among supporting services, most of the components of terrestrial habitat services showed positive responses while most of components of aquatic habitat showed negative responses to MPB outbreaks. Nutrient cycling also showed a short-term negative effect.

Cultural services:

- Tourism and recreation do not show any documented detrimental effects in response to the current MPB outbreak, while the outbreak has potential negative effects on services related to landscape aesthetics or scenic beauty. The effects of MPB infestations on public perceptions appear to be complex and much is not yet understood due to limited studies, therefore further investigations are recommended to explore the ramifications of the MPB outbreak and societal response to it.

All evidence suggests that MPB outbreaks in combination with salvage logging significantly increase impacts on most of the ES, while in the absence of salvage logging MPB has a comparatively lesser impact. Consequently, any management response to natural disturbances like MPB need to carefully balance economic concern for recouping the lost timber value, and preserving the non-timber benefits with the ecological realization that disturbance is an integral part of forest health and function.

\section{Future direction of research}

Based on this review it is clearly evident that in spite of numerous studies, little is known about the long-term effect of MPB outbreaks on different ecosystem functions and society (such as 
706

707

708

709

710

711

712

713

714

715

716

717

718

719

720

721

722

723

724

725

726

727

728

729

habitat quantity and quality, hydrological integrity, forest fire dynamics, carbon cycling, endangered plant and wildlife species, and spiritual or aesthetic factors including the socio-economic impact on forest dependent communities of affected regions) (Table 1). Therefore, future research should address the following points to increase our understanding of the causes and consequences:

- It is necessary to distil the essential climatic, ecosystem components, watershed, social, and beetle attack variables that impact different ecosystem services supply and demand to support predictive understanding and a model for future MPB management that works across the different scales of distance and time.

- In addition to detailed studies, mapping the influences of MPB outbreak on local, regional, and national scales will provide a basis to identify where and which part of the landscape has been most severely impacted by the MPB and requires attention from a mitigation program.

- Studies on societal response to MPB attacks could provide the basis to identity at-risk forest dependent communities and their degree of vulnerability to MPB attack.

- Up to now, management responses have emphasized only short-term exploitation of a single provisioning (timber) value, rather than long-term stewardship of multiple ecosystem services and respect for all forest ES values. MPB and ecosystem management decisions, therefore, should be considered in terms of long-term trade-offs between the costs and benefits among ES. Although our understanding of the complex nature of ecosystems, the inter-relationships between processes at the landscape scale, and the benefits they provide to humans is still limited, a better understanding of the dynamics of multiple ES impacted by the current MPB outbreak may help to quantify the provisioning of multiple services, their trade-offs, and the synergies among them. Such an understanding would greatly contribute to the sustainable management of 

and future forest disturbances.

\section{Acknowledgements}

733

This research was supported by a grant to Dr. Lael Parrott and Dr. Scott Heckbert from the Natural Science and Engineering Research Council of Canada (grant no. NET GP 434810-12) to the TRIA Network, with contributions from Alberta Agriculture and Forestry, Foothills Research Institute, Manitoba Conservation and Water Stewardship, Natural Resources Canada - Canadian Forest Service, Northwest Territories Environment and Natural Resources, Ontario Ministry of Natural Resources and Forestry, Saskatchewan Ministry of Environment, West Fraser, and Weyerhaeuser. We would like to thank Rebekka Augustine for editorial revisions to the manuscript. We also thank three anonymous reviewers and the associate editor of Canadian Journal of Forest Research for their constructive suggestions that greatly improved the overall manuscript.

\section{References}

Abbott, B., Stennes, B., van Kooten, G.C., 2008. An Economic Analysis of Mountain Pine Beetle Impacts in a Global Context. REPA working paper 2008-02, University of Victoria, BC, pp 25.

Alberta Agriculture, Food and Rural Development 2006. Fresh Water Aquaculture Industry, Agriculture Business Profiles. Alberta Ministry of Agriculture, Food \& Rural Development. http://www1.agric.gov.ab.ca/\$department/deptdocs.nsf/all/agdex4258\#Economic (accessed 24 May 2015)

Alberta Environment and Sustainable Resources Development (AESRD). 2012a. Economic Impact of Alberta's Forest sector 2012. Gov. of Alberta, AB. http://esrd.alberta.ca/lands-forests/forestbusiness/documents/ForestryEconomicImpactReport-May2013.pdf (accessed 26 May 2015)

Alberta Environment and Sustainable Resources Development (AESRD). 2012b. Sustainable Forest Management 2012 Facts \& Statistics, Gov. of Alberta, AB. http://esrd.alberta.ca/lands-forests/forest- 

management/forest-management-facts-statistics/documents/FMPlan-CurrentFactsAndStatistics-2011.pdf (accessed 24 May 2015)

Alberta Government. 2012. Highlights of the Alberta Economy 2012. Edmonton, Ab. http://www.albertacanada.com/SP-EH_highlightsABEconomy.pdf (accessed 22 May 2015)

Alberta Tourism, Parks and Recreation. 2014. Tourism, Parks and Recreation, Annual Report 2013-2014, Gov. of Alberta, http://tpr.alberta.ca/about/annual-report/pdf/2014/AnnualReport-with-statements.pdf (accessed 22 May 2015)

Alfaro, R.I., Campbell, E., Hawkes, B.C., 2010.Historical frequency, intensity and extent of mountain pine beetle disturbance in British Columbia. Natural Resources Canada, Canadian Forest Service, Pacific Forestry Centre, Victoria, BC. MPB Working Paper 2009-30, pp 52.

Amman, G.D., McGregor, M.D., Cahill, D.B., Klein, W.H. 1977. Guidelines for reducing losses of lodgepole pine to the mountain pine beetle in unmanaged stands in the Rocky Mountains. USDA Forest Service, General Technical Report INT-36. pp19.

Amman, G.D., Anhold, J.A. 1989. Preliminary evaluation of hazard and risk variables for mountain pine beetle infestations in lodgepole pine stands. In Proceedings - Symposium on the management of lodgepole pine to minimize losses to the mountain pine beetle. Kalispell, MT, 12-14 July 1988. Edited by G.D. Amman USDA Forest Service, General Technical Report INT-262. pp 22-27

Amoroso, M.M., Coates, K.D., Astrup, R. 2013. Stand recovery and self-organization following large-scale mountain pine beetle induced canopy mortality in northern forests. For. Ecol. Manage. 310, 300-311. doi:10.1016/j.foreco.2013.08.037

Arora, V.K., Peng, Y., Kurz, W.A., Fyfe, J.C., Hawkins, B., Werner, A.T. 2016. Potential near-future carbon uptake overcomes losses from a large insect outbreak in British Columbia, Canada, Geophys. Res. Lett., 43, doi:10.1002/ 2015GL067532

Axelson J., Alfaro, R., Hawkes, B. 2009. Influence of fire and mountain pine beetle on the dynamics of lodgepole pine stands in British Columbia, Canada. For. Ecol. Manage. 257, 1874-1882. doi:10.1016/j.foreco.2009.01.047 
780 Bailey, M., Sumaila, U.R. 2013. Freshwater Angling and the BC Economy, Freshwater Fisheries Society of 781 BC, Economic impact report, Victoria, pp 12

782 BC Forest Practices Board. 2007. The Effect of Mountain Pine Beetle Attack and Salvage Harvesting On 783 Streamflows. Special Investigation, FPB/SIR/16, Victoria, pp 27

784

785

786

BC Ministry of Environment 2013. BC Parks Year End Report 2012/13. Statistic Report http://www.env.gov.bc.ca/bcparks/research/statistic_report/statistic_report_2013.pdf (accessed 22.June 2015)

BC Ministry of Environment. 2010. BC Parks Year End Report 2009/10, Statistic Report http://www.env.gov.bc.ca/bcparks/research/year_end_report/year_end rep_2010.pdf (accessed 14 April 789 2015)

790

791 792

BC Ministry of Environment. 2008b. BC Parks Year End Report 2007/08. Statistic Report http://www.env.gov.bc.ca/bcparks/research/year_end_report/year_end_rep_2008.pdf (accessed 14.June 2015)

BC Ministry of Forests, Mines Lands. 2010. $\neg$ The State of British Columbia’s Forests, Third Edition, Victoria, BC, http://www.for.gov.bc.ca/hfp/sof/2010/SOF 2010 Web.pdf (accessed 14.March 2015)

BC Ministry of Forests, Lands and Natural Resource Operations. 2012. Resource Values Assessment: Recreation, A Mid-term Timber Supply Action Plan. http://www.for.gov.bc.ca/hfp/mountain pine beetle/mid-term-timber-supplyproject/Recreation_summary_june11.pdf (accessed 11.April 2015)

BC Ministry of Forests and Range. 2010. Visual impact of mountain pine beetle attack and resulting salvage operations in British Columbia: a public perception study. Forest Practices Branch. Victoria, BC.23p

Bentz, B.J., Régnière, J., Fettig, C.J. et al. 2010. Climate Change and Bark Beetles of the Western United States and Canada: Direct and Indirect Effects. BioScience, 60(8),602-613

Bisson, P. A., Bilby, R.E., Bryant, M.D., Dollof, C.A., et al. 1987. Large woody debris in forest streams in the Pacific Northwest: Past, present, and future. In Stream Management: Forestry and Fisheries Interaction. 805 Edited by Ernest O. Salo, Terrance W. Cundy. University of Washington, Washington, pp. 143-190. 
806

807

808

809

810

811

812

813

814

815

816

817

818

819

820

821

822

823

824

825

826

827

828

829

830

831

Bogdanski, B., Sun,L., Peter,B., Stennes, B. 2011. Markets for forest products following a large disturbance: Opportunities and challenges from the mountain pine beetle outbreak in western Canada. Canada Forest Services, Report BC-X-429. pp 68.

Bonnot, T.W., Rumble, M.A., Millspaugh, J.J. 2008. Nest success of black-backed woodpeckers in forests with mountain pine beetle outbreaks in the Black Hills, South Dakota. The Condor 110(3):450-457

Boon, S. 2007. Snow accumulation and ablation in a beetle-killed pine stand in Northern Interior British Columbia. J. Ecosyst. Manage. 8, 1-13.

Bourbonnais, M. L., Nelson, T. A. Wulder, M. A. 2014. Geographic analysis of the impacts of mountain pine beetle infestation on forest fire ignition. Can. Geogr, 58, 188-202. doi: 10.1111/j.15410064.2013.12057.x

Bravi, B., Chapman, B.K. 2009. Managing for pine mushrooms through the mountain pine beetle epidemic in the west Chilcotin. B.C. Min. For. Range, Kamloops, B.C. Exten. Note 09. pp 7

Brown, S., Schreier, H. 2009. Water quantity and quality related to rates of pine beetle infestation and salvage logging: A regional comparison. Water quality technical report, MPB Project \#7.31. pp 24

Brown, M., T.A. Black, T.A., Nesic, Z., et al. 2010. Impact of mountain pine beetle on the net ecosystem production of lodgepole pine stands in British Columbia. Agric. For. Meteorol. 150, 254-264. doi:10.1016/j.agrformet.2009.11.008

Buhyoff, G.J., Wellman, J.D., Daniel, T.C., 1982. Predicting scenic quality of mountain pine beetle and western spruce budworm damaged forest vistas. For. Sci. 28, 827-838.

Bunnell, F.L., Kremsater, L.L., Houde, I. 2011. Mountain pine beetle: A synthesis of the ecological consequences of large-scale disturbances on sustainable forest management, with emphasis on biodiversity. Canadian Forest Service, Victoria, BC, pp 99.

Bunnell, F., Squires, K.A., Houde, I. 2004. Evaluating effects of large-scale salvage logging for mountain pine beetle in terrestrial and aquatic vertebrates. Natural Resources Canada, Victoria, BC. pp 57

Burton, P.J. 2006. Restoration of forests attacked by mountain pine beetle: Misnomer, misdirected, or mustdo? J. Ecosyst. Manage. 7(2),1-10. 
832 Burton, H.P. 2010. Striving for sustainability and resilience in the face of unprecedented change: the case of 833 the mountain pine beetle outbreak in British Columbia. Sustainability 2,2403-2423. doi:10.3390/su2082403

835

836

837

838

839

840

841

842

843

844

Caldwell, M.K. 2012. Impacts of mountain pine beetle (Dendroctonus Ponderosae) and fire disturbances on forest ecosystem carbon dynamics and species composition. MSc Thesis, Uni.of Colorado, USA

Carroll, A.L., Régnière, J. Logan, J.A., Taylor, S.W., Bentz, B., Powell, J.A. 2006. Impacts of climate change on range expansion by the mountain pine beetle. Natural Resources Canada, Canadian Forest Service, Pacific Forestry Centre, Victoria, BC. MPB Working Paper 2006-14. pp 20.

Chan-McLeod, A.C.A. 2006. A review and synthesis of the effects of unsalvaged mountain-pine-beetleattacked stands on wildlife and implications for forest management. J. Ecosyst. Manage. 7, 119-132.

Cheng, J.D. 1989. Streamflow changes after clear-cut logging of a pine beetle-infested watershed in southern British Columbia, Canada. Water Resources Research 25, 449-456.

Cichowski, D., Haeussler, S. 2013. The Response of Caribou Terrestrial Forage Lichens to Mountain Pine Beetles and Forest Harvesting in the East Ootsa and Entiako areas. Annual Report-year 11, Habitat Conservation Trust Foundation, Victoria, and Ministry of Forests, Lands and Natural Resource Operations Smithers, BC. pp 49.

Cichowski, D. 2010. Tweedsmuir-Entiako Caribou Project: Effects of a Mountain Pine Beetle Epidemic on Northern Caribou Habitat Use - Final Report. Prepared for the Bulkley Valley Centre for Natural Resources Research and Management, Smithers, BC. pp 66.

Cigan, P.W., Karst, J., Cahill Jr, J.F., Sywenky, A.N., Pec, G.J., Erbilgin, N. 2015. Influence of bark beetle outbreaks on nutrient cycling in native pine stands in western Canada. Plant Soil. 390, 29-47. doi:10.1007/s11104-014-2378-0

Clow, D. W., Rhoades, C., Briggs, J., Caldwell, M., Lewis, W. M. 2011. Responses of soil and water chemistry to Mountain Pine Beetle induced tree mortality in Grand County, Colorado, USA. Appl. Geochem. 26, S174-S178 
857 Coates, K.D., Glover, T., Henderson, B., 2009. Abundance of secondary structure in lodgepole pine stands

858 affected by the mountain pine beetle in the Cariboo-Chilcotin. Canadian Forest Service, Pacific Forestry

859 Centre, Mountain Pine Beetle Working Paper 2009-20. Victoria, BC. pp 37

860 Collins, B.J., Rhoades, C.C., Battaglia, M.A., Hubbard, R.M. 2012. The effects of bark beetle outbreaks on

861 forest development, fuel loads and potential fire behavior in salvage logged and untreated lodgepole

862 pine forests. For Ecol Manage 284,260-268. doi:10.1016/j.foreco.2012.07.027

863 Coops, N.C., Timko, J.A., Wulder, M.A., White, J.C., Ortlepp, S.M. 2008. Investigating the effectiveness of

864 Mountain Pine Beetle mitigation strategies. Int. J. Pest Manage. 54 (2), 151-165.

865 doi:10.1080/09670870701805737

866 Costanza, R., de Groot, R., Sutton, P., et al.2014. Changes in the global value of ecosystem services, Global.

867 Environ. Chang. 26,152-158. doi:10.1016/j.gloenvcha.2014.04.002

868 Costanza, R., dArge, R., de Groot, R., et.al. 1997. The value of the world's ecosystem services and natural 869 capital. Nature. 387, 253-260.

870 Cullings, K.W., New, M.H., Makhija, S., Parker, V.T. 2003. Effects of litter addition on ectomycorrhizal 871 associates of a lodgepole pine (Pinus contorta) stand in Yellowstone National Park. Appl. Environ. 872 Microbiol. 69(7),3772-3776. doi: 10.1128/AEM.69.7.3772-3776.2003 Dahlsten, D.L., Rowney, 873 D.L.1983. Insect pest management in forest ecosystems. Environ. Manage. 7,65-72.

874 Daniel, T.C., Orland, B., Hetherington, J., Paschke, J.L., 1991. Public perception and attitudes regarding 875 spruce bark beetle damage to forest resources on the Chugach National Forest, Alaska. Final Report 876 Prepared for the USDA Forest Service, vol. 10. Forest Pest Management Region, Fort Collins, CO. 877 Daily, G. 1997. What are Ecosystem Services? In Nature's Services: Societal Dependence on Natural 878 Ecosystems. Edited by G. C. Daily. Island Press, Washington, DC. pp 1-11.

879 Drever, M.C., Martin, K. 2007. Spending time in the forest: Responses of cavity-nesters to temporal changes 880 in forest health and environmental conditions in interior British Columbia. In Temporal dimensions of 881 landscape ecology: Wildlife responses to variable resources, Edited by, J.A., Bissonette, I. Storch. $882 \quad$ Springer, New York. pp. 236-251 
883 Dhar, A., Balliet, N.A., Runzer, K.D, Hawkins, C.D.B. 2015. Impact of a mountain pine beetle outbreak on 884 young lodgepole pine stands in central British Columbia. Forests 6, 3483-3500, doi:10.3390/f6103483

885 Dhar, A., Parrott, L. 2015. Salvage logging after mountain pine beetle outbreaks reduces the social-ecological 886 resilience of forest landscapes. In Mountain pine beetle information exchange forum Edmonton, AB. 22-

887 23 July 2015. Edited by McClain, K. Edmonton, Alberta, pp.17

888

Dhar, A., Coates, K.D., Rogers, B., Hardy, K. 2013. Impact of mountain pine beetle on mid-term timber 889 supply in sub boreal spruce zone of British Columbia. In16th International Boreal Forest Research 890 Association (IBFRA), Edmonton, AB. 7-10, October 2013. Edited by Phil G. Comeau, Edmonton,

891 Canada, pp. 28

892

Dhar, A., Hawkins, C.D.B., 2011. Regeneration and growth following mountain pine beetle attack: a synthesis of knowledge. J. Ecosyst. Manage. 12, 1-16.

894

Duchesne, L.C., Wetzel, S., 2002. Managing timber and non-timber forest product resources in Canada's forests: needs for integration and research. For. Chron. 78, 837-842

Edwards, M., Krawchuk, M.M., Burton, P.J. 2015. Short-interval disturbance in lodgepole pine forests, British Columbia,Canada: Understory and overstory response to mountain pine beetle and fire. For. Ecol.

Embrey, S., Remais, J. V., Hess, J. 2012. Climate Change and Ecosystem Disruption: The Health Impacts of 900 901 the North American Rocky Mountain Pine Beetle Infestation. Am. J. Public. Health. 102,818-827. doi: 10.2105/AJPH.2011.300520

Emmela, C., Paul-Limoges, E., Bowled, R., Black, T.A. Andreas Christen, A. 2014. Vertical distribution of carbon dioxide sources and sinks in a recovering mountain pine beetle-attacked lodgepole pine stand. Agric. For. Meteorol. 195-196, 108-122. doi:10.1016/j.agrformet.2014.04.014 Canada. http://www.ec.gc.ca/publications/A91164E0-7CEB-4D61-841C-BEA8BAA223F9/Executive- 
908 Erbilgin, N., Ma, C., Whitehouse, C., Shan, B., Najar, A., Evenden, M. 2014. Chemical similarity between 909 historical and novel host plants promotes range and host expansion of the mountain pine beetle in a

910

911

912

913

914

915

916

917

918

919

920

921

922

923

924

925

926

927

928

929

930

931

932

933 naïve host ecosystem. New Phytol. 201,940-950, doi:10.1007/s00442-016-3559-8

Fall, A., Shore, T.L., Safranyik, L., Riel, W.G., Sachs, D. 2004. Integrating landscapescale mountain pine beetle projection and spatial harvesting models to assess management strategies. In Challenges and Solutions: Proceedings of the Mountain Pine Beetle Symposium. Kelowna, BC. October 30-31, October 2003. Edited by T.L. Shore, J.E. Brooks, J.E. Stone. Natural Resources Canada, Canadian Forest Service, Pacific Forestry Centre, Victoria, BC, Information Report BC-X-399. pp 114-132.

Faber, S., Costanza, R., Childers, D.L., Erickson, J., et al. 2006. Linking ecology and economics for ecosystem management. BioScience 56, 121-133.

Ferrari, M.R., Miller, J.R., Russell, G.L. 2007. Modeling changes in summer temperature of the Fraser River during the next century. J. Hydrol., 342, 336-346. doi:10.1016/j.jhydrol.2007.06.002

Fettig, C.J., Klepzig, K.D., Billings, R.F., Munson, A.S., Nebeker, T.E., Negron, J.F.,Nowak, J.T. 2007. The effectiveness of vegetation management practices for prevention and control of bark beetle infestations in coniferous forests of the western and southern United States. For. Ecol. Manage. 238, 24 -53.

Fettig, C.J., Reid, M.L., Bentz, B.J., Sevanto, S., Spittlehouse, D.L., Wang,T. 2013a. Changing climates, changing forests: A western North American perspective. J. For. 111, 214-228. doi: http://dx.doi.org/10.5849/jof.12-085

Fettig, C.J., Munson, A.S., Grosman, D.M., Bush, P.B. 2013b. Evaluations of emamectin benzoate and propiconazole for protecting individual Pinus contorta from mortality attributed to colonization by Dendroctonus ponderosae and associated fungi. Pest Manage. Sci. 70,771-778, doi: 10.1002/ps.3612.Fettig, C.J., Gibson, K.E., Munson, A.S., Negrón, J.F. 2014. Cultural practices for prevention and mitigation of mountain pine beetle infestations. For. Sci. 60:450-463, http://dx.doi.org/10.5849/forsci.13- 032

Foley JA, DeFries R, Asner GP, Barford C, et al. 2005. Global Consequences of Land Use, Science, 309, 570 - 574. doi : 10.1126/science. 1111772 
934 Forest Practices Board. 2007. The Effect of Mountain Pine Beetle Attack and Salvage Harvesting On 935 Streamflows. Special Investigation, FPB/SIR/16, Victoria, pp 29

936 Gillette, N.E., Wood, D.L., Hines, S.J., Runyon, J.B., Negrón, J.F. 2014. Consequences of mountain pine 937 beetle treatment decisions. For. Sci., 60,527-538. http://dx.doi.org/10.5849/forsci.13-040

938

939

940

941

942

943

944

945

946

947

948

949

950

951

952

953

954

955

956

957

958

Griffin, J.M., Turner, M.G., Simard, M. 2011. Nitrogen cycling following mountain pine beetle disturbance in lodgepole pine forests of greater yellowstone. For. Ecol. Manage. 261(6),1077-1089. doi: 10.1 016/j.foreco.201 0.12.031

Hamer, D. 1996. Buffaloberry [Shepherdia Canadensis (L.) Nutt.] fruit production in fire-successional bear feeding sites. J. Range. Manage. 46, 520-529

Hansen, E.M., Amacher, C.M., Miegroet, H.V., Long,J.N., Ryan, M.G. 2015. Carbon Dynamics in Central US Rockies Lodgepole Pine Type After Mountain Pine Beetle Outbreaks. For. Sci. 61, 665-679. doi: http://dx.doi.org/10.5849/forsci.14-094

Hansen, E.M. 2014. Forest development and carbon dynamics after mountain pine beetle outbreaks. For. Sci. 60(3),476 - 488. doi: http://dx.doi.org/10.5849/forsci.13-039

Hart, S.J., Schoennagela, T., Veblena, T.T., Chapmana, T.B. 2015. Area burned in the western United States is unaffected by recent mountain pine beetle outbreaks, Proc. Natl. Acad. Sci.112, 4375-4380. doi: $10.1073 /$ pnas. 1424037112

Harveya, B.J., Donatob, D.C., Turnera, M.G. 2014. Recent mountain pine beetle outbreaks, wildfire severity, and postfire tree regeneration in the US Northern Rockies. Proc. Natl. Acad. Sci. 111,15120-15125, doi: 10.1073/pnas. 1411346111

Hassan, M.; Hogan, D.; Bird, S., 2008. Mountain pine beetle impacts on channel morphology and woody debris in forested landscapes. Natural Resources Canada, MPB Working Paper2008-07. pp 41

Hawkins C.D.B., Dhar A., Balliet N. 2013. Radial growth of residual overstory trees and understory saplings after mountain pine beetle attack in central British Columbia. For. Ecol. Manage. 310,348-356. doi:10.1016/j.foreco.2013.08.035 
959 Hawkins, C.D.B., Dhar, A., Balliet, N.A., Runzer, K.D., 2012. Residual mature trees and secondary stand 960 structure after mountain pine beetle attack in central British Columbia. For. Ecol. Manage.277,107-115.

961

962

963

964

965

966

967

968

969

970

971

972

973

974

975

976

977

978

979

980

981

982

983 doi:10.1016/j.foreco.2012.04.023

Hélie, J.F., Peters, D.L., Tattrie, K.R., Gibson, J.J. 2005. Review and synthesis of potential hydrologic impacts of mountain pine beetle and related harvesting activities in British Columbia. Canadian Forest Service, Victoria, BC. MPB Working Paper 2005-23. pp 26

Hicke, J.A., Johnson, M.C., Hayes, J.L., Preisler, H.K. 2012a. Effects of bark beetle-caused tree mortality on wildfire. For. Ecol. Manage. 271,81-90. doi:10.1016/j.foreco.2012.02.005

Hicke, J.A., Allen,C.D., Desai, A., Dietze, M.C., Hall, R.J., Hogg, E.H., Kashian, D.M., et al. 2012b. Effects of biotic disturbances on forest carbon cycling in the United States and Canada. Global Change Biol. 18,7-34. doi: 10.1111/j.1365-2486.2011.02543.xHinch, S., Mellina, E. 2008. Stream habitat and bull trout (Salvelinus confluentus) responses to MPB riparian salvage harvesting in north-central British Columbia. FIA-FSP Project Y091046. Victoria, BC. pp12

Hoffman, C.M. 2011. Numerical Simulation of Crown Fire Hazard in Bark Beetle Infested Lodgepole Pine Forests. PhD Dissertation. University of Idaho. 96 p.

Hopping, G.R.; Mathers, W.G. 1945. Observations on outbreaks and control of the mountain pine beetle in the lodgepole pine stands of western Canada. The Forestry Chronicle, June 1945,1-11.

Jenkins, M.J., Hebertson, E., Page, W., Jorgenson, C.A. 2008. Bark beetles, fuels, fires and implications for forest management in the Intermountain West. For. Ecol Manage. 254,16-34 doi:10.1016/j.foreco.2007.09.045

Jenkins, M.J., Runyon, J.B., Fettig, C.J., Page, W.G., Bentz, B.J. 2014. Interactions among the mountain pine beetle, fires, and fuels. For. Sci. 60,489-501, http://dx.doi.org/10.5849/forsci.13-017

Johnson, S.L., Jones, J.A. 2000. Stream temperature response to forest harvest and debris flows in western Cascades, Oregon. Canadian Journal of Fish and Aquatic Sciences 57,30-39. 
984 Johannes, M.R.S., Kenney, A., Pouliotte, J. Steele, D. 2007. Mountain Pine Beetle Threats to Salmon and 985 Fisheries Resources. In BC: Proceedings of the Pacific Salmon Foundation and Fraser Basin Council 986 Workshop. January 30-31, 2007, Prince George. BC. pp 71.

987

988

989

990

991

992

993

994

995

996

997

998

Jolly, W.M., Parsonsa, R.A., Hadlowa, A. M., Cohna, G. M., McAllister, S.S. et al. 2012. Relationships between moisture, chemistry, and ignition of Pinus contorta needles during the early stages of mountain pine beetle attack. For. Ecol. Manage. 269,52-59. doi:10.1016/j.foreco.2011.12.022

Keville, M.P., Reed, S.C., Cleveland, C.C. 2013. Nitrogen Cycling Responses to Mountain Pine Beetle Disturbance in a High Elevation Whitebark Pine Ecosystem. PLoS ONE 8(6), e65004. doi:10.1371/journal.pone.0065004

Kimmins, J.P. 1987. Forest ecology. Macmillan Publishing Company, New York.pp531.

Klutsch, G.J., Battaglia, M.A., West,D.R., Costello, S.L.,Negrón, J.F. 2011. Evaluating Potential Fire Behavior in Lodgepole Pine-Dominated Forests after a Mountain PineBeetle Epidemic in North-Central Colorado. West J. Appl. For. 26(3) 2011

Kovacic, D.A., Dyer, M.I., Cringan, A.T. 1985. Understory biomass in ponderosa pine following mountain pine beetle infestation. For. Ecol. Manage. 13, 53-67. doi:10.1016/0378-1127(85)90005-2

Kulakowski, D., Jarvis, D. 2011. The influence of mountain pine beetle outbreaks and drought on severe wildfires in northwestern Colorado and southern Wyoming: A look at the past century. For. Ecol. Manage. 262, 1686-1696. doi:10.1016/j.foreco.2011.07.016

Kurz,W.A., Dymond, C.C., Stinson, G., Rampley, G. J., et al. 2008. Mountain pine beetle and forest carbon feedback to climate change, Nature, 452,987-990

Lal, R., Lorenz K., Hüttl, R.R.J., Schneider, B.U., von Braun, J. 2013. Ecosystem Services and Carbon Sequestration in the Biosphere. Springer, Dordrecht, Netherlands: pp 464

Larkin, G.A., Slaney, P.A., Warburton, P., Wilson, A.S. 1998. Suspended sediment and fish habitat sedimentation in central interior watersheds of British Columbia. Ministry of Environment, Lands and Parks. Watershed Restoration Management Report No. 7, pp31 
1009 Lindenmayer, D.B., Burton, P.J., Franklin, F.J. 2008. Salvage logging and its ecological consequences. Island $1010 \quad$ press, Washington, pp 227

1011 Litterman, B. 2013. What Is the Right Price for Carbon Emissions? Regulation ,summer edition, 38-43

1012 Logan, J.A., Powell, J.A. 2001. Ghost forests, global warming, and the mountain pine beetle (Coleoptera: $1013 \quad$ Scolytidae). Am. Entomol. 47,160-172.

1014 Lotan, J.E., Brown, J.K., Neuenschwander, L.F., 1985. Role of fire in lodgepolepine ecosystems. In 1015 Lodgepole Pine: The Species and its Management. Edited by D. Baumgartner, Krebill, R., Arnott, J., 1016 Weetman, G. Washington State University, Pullman, WA, pp. 133-152.

1017 Lynch, H.J., Renkin, R.A., Crabtree, R.L., Moorcroft, P.R., 2006. The influence of previous mountain pine 1018 beetle (Dendroctonus ponderosae) activity on the 1988 Yellowstone fires. Ecosystems 9, 1318-1327. 1019 Maloney, D. 2004. The effects of riparian harvesting on fish habitat and ecology of small headwater streams. 1020 FIA-FSP Project R04-032, Year-end Report, pp 7

1021 Mann, A., Tam, C., Higgins, C., Rodrigues, L. 2007. The association between drinking water turbidity and 1022 gastrointestinal illness: a systematic review. BMC Public Health, 7, pp256.

1023 Martin, K., Norris, A., Drever, M. 2006. Effects of bark beetle outbreaks on avian biodiversity in the British 1024 Columbia interior: Implications for critical habitat management. J. Ecosyst. Manage. 7, 10-24. 1025 Mathys, A., Black, T.A., Nesic, Z, Nishio, G. et al. 2013. Carbon balance of a partially-harvested mixed 1026 conifer forest following mountain pine beetle attack and its comparison to a clearcut. Biogeosciences 10,5451-5463, doi:10.5194/bg-10-5451-2013

McCullough, D.G., Werner, R.A., Neumann, D. 1998. Fire and insects in northern and boreal forest ecosystems of North America. Annu. Rev. Entomol. 4, 107-127.doi: 10.1146/annurev.ento.43.1.107

McFarlane, B.L., Watson, D.O. 2008. Perceptions of ecological risk associated with mountain pine beetle (Dendroctonus ponderosae) infestations in Banff and Kootenay National Parks of Canada. Risk Analysis. 28, pp 203-212. 
1033 McIntosh, A.C.S., Macdonald, S.E. 2013. Potential for lodgepole pine regeneration after mountain pine beetle 1034 attack in newly invaded Alberta stands. For. Ecol. Manage. 295, 11-19.

1035 doi:10.1016/j.foreco.2012.12.050

1036

Michael, M., Cluny, S. Carossa, W. 2011. Post-mountain pine beetle recreational usage survey, Mid-term 1037 timber supply Report appendix 8. pp80.

1038

Meigs, G.W., Campbell, J.L., Zald, H.S., Bailey, J.D., Shaw, D.C., Kennedy, R.E. 2015. Does wildfire 1039 likelihood increase following insect outbreaks in conifer forests? Ecosphere 6, art118. http://dx.doi.org/10.1890/ES15-00037.1

Meitner, M., South, C., Wieler, C. 2011.Post-mountain pine beetle recreational usage survey: project final report. BC Ministry of Forest, Lands and Natural Resource Operations. Victoria, British Columbia, pp81

Mikkelson, K., Bearup L.A., Maxwell, R.M., Stednick, J.D., McCray, J.E., Sharp, J.O. 2013. Bark beetle infestation impacts on nutrient cycling, water quality and interdependent hydrological effects. Biogeochemistry 115,1-21, doi: 10.1007/s10533-013-9875-8

Mikkelson, K. M., Dickerson, E. R., McCray, J. E., Maxwell, R. M., Sharp, J. O. 2012.Water quality impacts from climate-induced forest die-off. Nature. Clim. Change.3, 218-222. doi:10.1038/nclimate1724

Millennium Ecosystem Assessment (MEA). 2005. Ecosystems and Human Well-Being: Synthesis Island Press, Washington, DC

Mitchell, D., Hobby, T., Brigham, T., Hamilton, E., Robertson, S. 2006. Canadian non-timber forest products: Strategies for sustainable management, community development and policy implementation. Sustainable Forest Management Network 2006 Conference, Sustaining Canada’s Forests: Building Momentum. Edmonton, Ab. 20 - 22, June 2006, Discussion Forum 7, Edmonton, Canada

Mitchell, R.G., Waring, R.H., Pitman, G.B. 1983. Thinning lodgepole pine increases vigor and resistance to mountain pine beetle. For. Sci. 29,204-211.

Meyers Norris Penny (MNP). 2015. BC Forest Industry Economic Impact Study. http://www.cofi.org/wpcontent/uploads/2015/01/bc industry_impact_01-2015.pdf (accessed 11 February 2016) 
1058

1059

1060

1061

1062

1063

1064

1065

1066

1067

1068

1069

1070

1071

1072

1073

1074

1075

1076

1077

1078

1079

1080

1081

1082

1083

Moola, F.M.,Mallik, A.U. 1998. Morphological plasticity and regeneration strategies of velvet leaf blueberry (Vaccinium myrtilloides Michx.) following canopy disturbance in boreal mixedwood forests. For. Ecol. Manage. 111, 35-50

Mooney, H.A., Ehrlich, P.R. 1997. Ecosystem services: A fragmentary history. In Nature’s Services: Societal Dependence on Natural Ecosystems, Edited by Daily, G. Island Press, Washington, pp 11-19.

Nealis, V., Peter, B. 2008. Risk assessment of the threat of mountain pine beetle to Canada's boreal and eastern pine forests. Information Report BC-X-417. Canada Forest Service, Victoria, BC, pp 38.

Negron, J.F., Bentz, B.J., Fettig, C.J., Gillette, N., et al. 2008. U.S. Forest Service bark beetle research in the western United States: Looking toward the future. J. Forestry 106, 325-331.

Negrón, J.F., Fettig, C.J. 2014. Mountain pine beetle, a major disturbance agent in US western coniferous forests: A synthesis of the state of knowledge. For. Sci. 60,409-413. doi: http://dx.doi.org/10.5849/forsci.13-169

Nielsena, S.E., Munrob, R.H.M., Bainbridgec, E.L., Stenhoused, G.B., Boycea, M.S. 2004. Grizzly bears and forestry II. Distribution of grizzly bear foods in clearcuts of west-central Alberta, Canada. For. Ecol. Manage. 199, 67-82

Olivotto, T. 1999. Pine mushroom and timber production in the Cranberry Timber Supply Area. Northwest Institute for Bioregional Research, Smithers, BC, pp12

Page, W., Jenkins, M.J. 2007. Predicted fire behavior in selected mountain pine beetle-infested lodgepole pine. For. Sci. 53, 662-674.

Page, W.G., Jenkins, M.J., Runyon, J.B. 2012. Mountain pine beetle attack alters the chemistry and flammability of lodgepole pine foliage. Can. J. Res. 42(8),1631-1647. doi:10.1139/x2012-094

Parks Canada. 2001.Resource conservation. Banff field unit. Report from the Field - 2011.pp 90. http://publications.gc.ca/collections/collection_2012/pc/R61-87-2011-eng.pdf (accessed 30.05.16)

Patriquin, M.N., Wellstead, A.M., White, W. A. 2007. Beetles, trees, and people: Regional economic impact sensitivity and policy considerations related to the mountain pine beetle infestation in British Columbia, Canada. Forest. Policy. Econ. 9, 938-946. doi:10.1016/j.forpol.2006.08.002 
1084 Pec, G.J., Karst, J., Sywenky, A.N., Cigan, P.W., Erbilgin, N., Simard, S.W., et al. (2015) Rapid Increases in 1085 Forest Understory Diversity and Productivity following a Mountain Pine Beetle (Dendroctonus 1086 1087

Perovich, P., Sibold, J.S. 2016. Forest composition change after a mountain pine beetle outbreak, Rocky 1088 1089 1090 
1109

1110

1111

1112

1113

1114

1115

1116

1117

1118

1119

1120

1121

1122

1123

1124

1125

1126

1127

1128

1129

1130

1131

1132

1133

1134

Resources Canada, Canadian Forest Service, Pacific Forestry Centre, Victoria, BC. Information Report BC-X-399. pp106-113.

Romme,W. H., Knight, D.H., Fedders, J., 1986. Mountain pine beetle outbreaks in the Rocky Mountains: Effects on fuels and fire in lodgepole pine forest. In Program of the Annual Meeting of the Ecological Society of America. Syracuse University, NY, pp 290.

Rosenberger, R.S., Smith, E.L. 1998. Assessing Forest Scenic Beauty Impacts of Insects and Management. Forest Health Technology Enterprise Team (FHTET), USDA Forest Service. Research Paper 98-08, Rosenberger,S.R., Bell, A.L., Champ, A.P., Eric M. White, E.M. 2013. Estimating the Economic Value of Recreation Losses in Rocky Mountain National Park Due to a Mountain Pine Beetle Outbreak, Western Economics Forum,12(1),31-39

Saab, V.A., Latif, Q.S., Rowland, M.M., Johnson,T.N. et al. 2014. Ecological Consequences of Mountain Pine Beetle Outbreaks for Wildlife in Western North American Forests. For. Sci. 60,539-559. doi: 10.5849/forsci.13-022

Safranyik, L., Carroll, A.L. 2006. The Biology and Epidemiology of the Mountain Pine Beetle in Lodgepole Pine Forests. In The Mountain Pine Beetle: a Synthesis of Biology, Management, and Impacts on Lodgepole Pine, Edited by L. Safranyik, B. Wilson. Natural Resources Canada, Victoria, pp 3-66

Safranyik L., Shrimpton, D.M., Whitney H.S. 1974. Management of lodgepole pine to reduce losses from the mountain pine beetle. Canadian Forest Service, Pacific Forest Research Centre, Victoria, BC. Forest Technical Report No. 1.

Shore T.L., Safranyik, L. 1992. Susceptibility and risk rating systems for the mountain pine beetle in lodgepole pine stands. Forestry Canada, Pacific Forestry Centre, Victoria, BC. Information Report BC$\mathrm{X}-336 . \mathrm{pp} 12$.

Shore, T.L., Safranyik, L. 2004. Mountain pine beetle management and decision support. In. Challenges and Solutions: Proceedings of the Mountain Pine Beetle Symposium. Kelowna, BC.30 -31, October 2003. Edited by T.L. Shore, J.E. Brooks, J.E. Stone Natural Resources Canada, Canadian Forest Service, Pacific Forestry Centre, Victoria, BC. Information Report BC-X-399. pp 97-105. 
1135 Safranyik, L., Wilson, B. 2006. The Mountain Pine Beetle: a Synthesis of Biology, Management, and Impacts 1136 on Lodgepole Pine, Natural Resources Canada, Victoria, BC. pp 304

1137

1138

1139

1140

1141

1142

1143

1144

1145

1146

1147

1148

1149

1150

1151

1152

1153

1154

1155

1156

1157

1158

1159

1160

Schoennagel, T., Veblen, T.T., Negron, J.F., Smith, J.M. 2012 Effects of Mountain Pine Beetle on Fuels and Expected Fire Behavior in Lodgepole Pine Forests,Colorado, USA. PLoS ONE 7(1), e30002. doi:10.1371/journal.pone.0030002

Schnorbus, M. 2011. A synthesis of the hydrological consequences of large-scale mountain pine beetle disturbance. Mountain Pine Beetle Working Paper 2010-01, Natural Resources Canada, Victoria, BC,

Schowalter, T.D. 2012.Insect Herbivore Effects on Forest Ecosystem Services, J. Sustainable For.3,518-536

Seip, D., Jones, E. 2010. Response of woodland caribou to partial retention logging of winter ranges attacked by mountain pine beetle. Annual Report.FSP Project \#Y102010.B.C. Ministry of Forests, Prince George, BC, pp 27

Sheppard, S., Picard, P. 2006. Visual-quality impacts of forest pest activity at the landscape level: A synthesis of published knowledge and research needs. Landscape. Urban. Plan.77, 321-342

Shore, L.T., Safranyik, L., Hawkes, C.B., Taylor, W.S. 2006. Effects of the mountain pine beetle on lodgepole pine stand structure and dynamics. In: The mountain pine beetle: A synthesis of biology, management, and impacts on lodgepole pine. Edited by L. Safranyik and B. Wilson. Natural Resources Canada, Victoria, B.C. pp 95-116.

Simard, M., Romme, W., Griffin, J., et al.2011. Do mountain pine beetle outbreaks change the probability of active crown fire in lodgepole pine forests? Ecol. Monogr. 81, 3-24

Six, L.D., Biber, E., Long, E. 2014. Management for Mountain Pine Beetle Outbreak Suppression: Does Relevant Science Support Current Policy? Forests. 5, 103-133. doi:10.3390/f5010103

Statistics Canada, 2012. Aquaculture Statistics 2011. Catalogue no. 23-222-X. http://www.aquaculture.ca/files/documents/AquacultureStatistics2011.pdf (accessed 23 May 2015)

Stednick, J. 2007. Preliminary assessment of water quantity and water quality changes in beetle-killed catchments in north-central Colorado. In Mountain Pine Beetle and Watershed Hydrology Workshop: preliminary results from BC, Alberta and Colorado. Edited by T.Redding, Kelowna BC. pp 27-28. 
1161 Steventon, J.D. 2015. Arboreal squirrel abundance in response to a gradient of mountain pine beetle attack in 1162 sub-boreal forests. J. Ecosyst. Manage. 15(1),1-12

1163 Stone, W.E., Wolfe, M.L. 1996. Response of understorey vegetation to variable tree mortality following a 1164 mountain pine beetle epidemic in lodgepole pine stands in northern Utah. Vegetatio 122, 1-12. doi: $1165 \quad 10.1007 / \mathrm{BF} 00052811$

1166

1167

1168

1169

1170

1171

1172

1173

1174

1175

1176

1177

1178

1179

1180

1181

1182

1183

1184

1185

1186

Sullivan, T.P., Sullivan, D.S., Lindgren, P.M.F., Ransome, D.B. 2010. Green-tree retention and life after the beetle: Stand structure and small mammals 30 years after salvage harvesting. Silva Fenn. 44,749-774.

Taylor, S. W., Carroll, A. L. 2004. Disturbance, forest age, and mountain pine beetle outbreak dynamics in BC: a historical perspective In. Challenges and Solutions: Proceedings of the Mountain Pine Beetle Symposium. Kelowna, BC.30 -31, October 2003. Edited by T.L. Shore, J.E. Brooks, J.E. Stone Natural Resources Canada, Canadian Forest Service, Pacific Forestry Centre, Victoria, BC. Information Report BC-X-399. pp. 41-51,

The Economics of Ecosystems and Biodiversity (TEEB). 2010. Mainstreaming the Economics of Nature: A Synthesis of the Approach, Conclusions and Recommendations of TEEB. Earthscan, London and Washington. pp 39

Walton, A. 2013. Provincial-Level Projection of the Current Mountain Pine Beetle Outbreak: Update of the infestation projection based on the Provincial Aerial Overview Surveys of Forest Health conducted from 1999 through 2012 and the BCMPB model (year 10). BC Ministry of Forests, Lands and Natural Resource Operations, http://www.for.gov.bc.ca/ftp/hre/external/!publish/web/bcmpb/year10/BCMPB.v10.BeetleProjection.Up date.pdf (accessed 14.April 2015)

Wong, C. 2008. Environmental Impacts of Mountain Pine Beetle in the Southern Interior, British Columbia Ministry of Environmen, Prince George, BC http://www.sibacs.com/wpcontent/uploads/2009/02/environmental-impacts-report-final.pdf (accessed 16 May 2015)

Wulder, M.A., Ortlepp, S.M., White, J.C., Coops, N.C., Coggins, S.B. 2009. Monitoring the impacts of mountain pine beetle mitigation. For. Ecol. Manage. 258,1181-1187. 
1187 Xue, D., Tisdell, C. 2001. Valuing ecological functions of biodiversity in Changbaishan Mountain Biosphere 1188 Reserve in Northeast China. Biodiversity and Conservation, 10(3), 467-481.

1189 Zwickel, H. 2012. Spot fishing in Alberta 2010: summary report from the eighth survey of recreational fishing 1190 in Canada. Alberta Sustainable Resources Development, Fisheries Management Branch Edmonton, $1191 \quad$ Alberta, pp 46.

1192 
Table 1. List of ecosystem services (ES) provided by pine forests impacted by mountain pine beetle (MPB) in western Canada

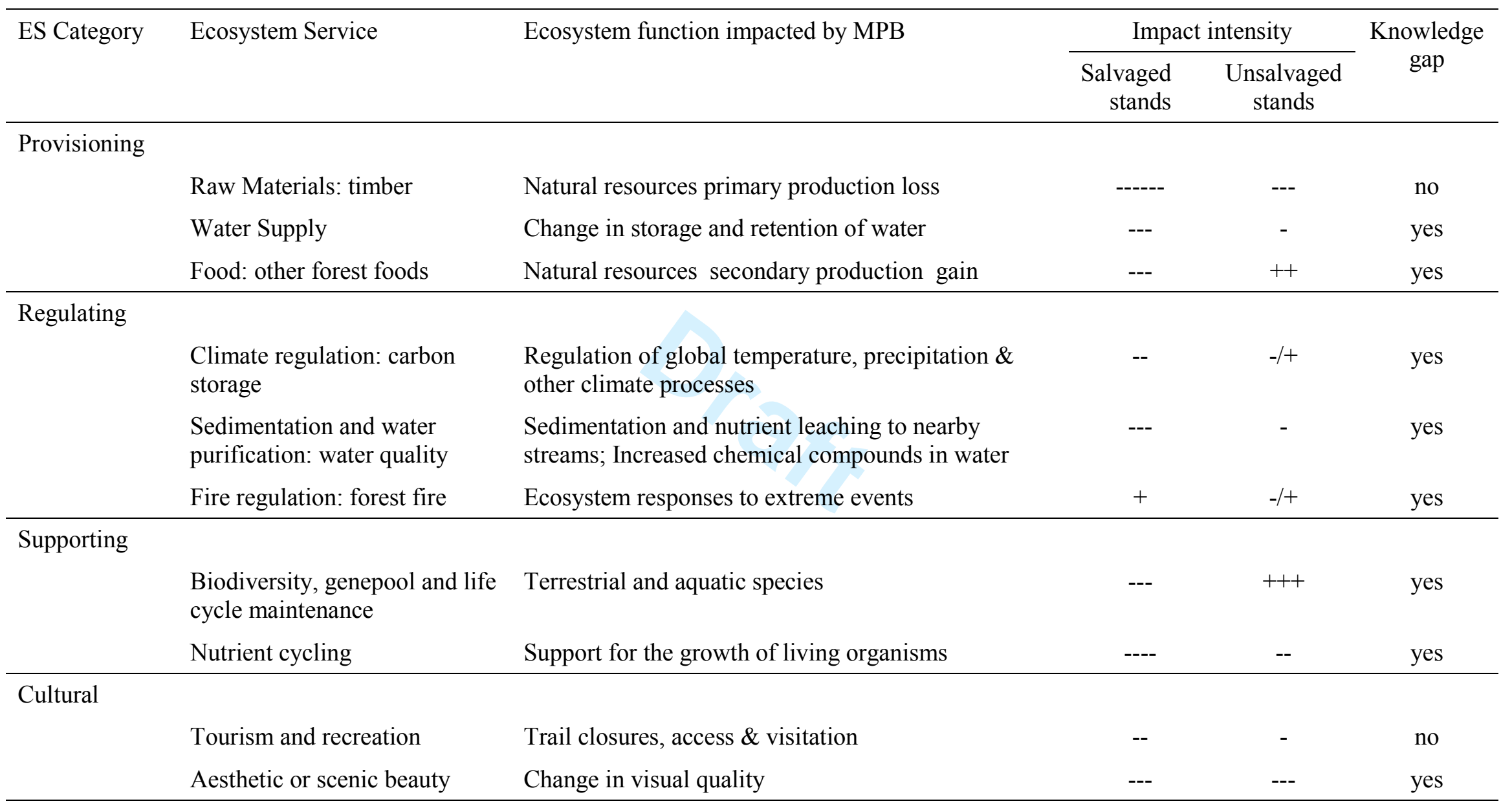

[Impact intensity was based on a qualitative assessment where intensity of plus $(+)$ and minus $(-)$ indicates the degree of positive and negative effect on the particular ecosystem service and together plus and minus (+/-) indicates effect in doubt] 